\title{
Urbanization and start-up rates in different geographies: Belgium, the Netherlands, and Sweden
}

\author{
Lianne Hans $(\mathbb{D})$ Sierdjan Koster
}

Accepted: 4 December 2017 / Published online: 20 December 2017

(C) The Author(s) 2017. This article is an open access publication
JEL classifications $\mathrm{R} 11 \cdot \mathrm{R} 12 \cdot \mathrm{L} 26$

\section{Introduction}

Cities are often seen as entrepreneurial hotbeds (Van Oort and Atzema 2004; Fritsch and Mueller 2007; Bosma et al. 2008; Audretsch et al. 2015). Densely populated areas offer urbanization advantages which stimulate start-up activity. Moreover, entrepreneurial people are likely to reside in urban areas (Glaeser et al. 2010; Duranton 2014; Westlund et al. 2014). Cities do not function in a vacuum, however, and the benefits or disadvantages of a city may very well depend on the configuration of the settlement pattern it is in (Eliasson and Westlund 2013; Meijers and Burger 2015). Two similar cities, one a functional center in a mostly rural area, the other part of large conurbation, may have distinct start-up patterns as a result. Indeed, the empirical evidence on the role of urbanization in start-up patterns is ambiguous and some authors find that startup rates are in fact higher in more sparsely populated rural areas (Fritsch and Falck 2007; Van Stel and Suddle 2008; Pettersson et al. 2010; Delfmann et al. 2014). In the Netherlands, there even appears to be a negative impact of urbanization on new firm formation (Van Stel and Suddle 2008; Delfmann et al. 2014). The mediating impact of settlement patterns on the role of urbanization in start-up patterns can provide an explanation for this.

The mediating effect of settlement patterns on startup activity has two elements. Firstly, there can be

S. Koster

e-mail: sierdjan.koster@rug.nl 
country differences in the overall level of population density, i.e., the level of urbanization. ${ }^{1}$ The overall level of urbanization is relevant as there is evidence that the effect of urbanization is not infinitely positive, and there are downsides to very high levels of urbanization (Bosma et al. 2008; Meijers et al. 2016). Frenken and Boschma (2007) suggest that a "ceiling" will be reached when the positive feedback processes are offset by negative feedback processes. In a scenario like this, a large city in a densely populated country can have lower start-up rates than surrounding regions, as these surrounding regions have a large enough population base to support positive urbanization economies without the negative effects of very high levels of urbanization found in the city. Indeed, for the Netherlands, it appears that urbanization disadvantages combined with increased possibilities for people to fulfill residential preferences outside cities, while retaining access to the urban centers, stimulates start-up activity in lessurbanized regions (Van Stel and Suddle 2008; Delfmann et al. 2014). A more technical way of seeing this is that the empirical relationship between start-up rates and urbanization can depend on the position in the overall distribution of urbanization and start-ups.

Secondly, access to cities can be an explaining factor of start-up patterns (Lavesson 2017). The concept of "borrowed size" (Alonso 1973) provides a useful explanation here. Originally applied to the situation where smaller cities borrow some of the urbanization benefits of their larger neighbors, it can be applied to rural-urban relationships as well. Access to the functions and networks of large cities can lead to higher average urbanization benefits in nearby areas, even though these functions are not present locally (Camagni et al. 2015; Meijers and Burger 2015; Meijers et al. 2016). As an illustration, Partridge et al. (2007) have shown that employment growth in rural areas is higher if the rural area is within daily commuting distance from an urban center. The same pattern may hold for start-up activity, and a rural region can experience relatively high start-up rates if it is located close to a major city. Yet, a relatively urbanized area in an otherwise distant peripheral region with weak connections to other major urban centers may have lower start-up rates than expected based on its urbanization level. Although access to cities is likely

\footnotetext{
${ }^{1}$ Population density is often used as a proxy for urbanization (see, for example, Verheul et al. 2002; Delfmann et al. 2014; Freire-Gibb and Nielsen 2014; Audretsch et al. 2015).
}

to be influenced by the overall level of density, it is also related to the urban settlement structure: some countries have one major urban area with a few smaller cities, while others have many cities of a similar size.

As of yet, there is no study known to us that explicitly considers the mediating role of national settlement patterns on the patterns of new firm formation. Given the ambiguous outcomes of different national studies, it is interesting to assess to what extent these differences can be explained by differences in settlement patterns. Therefore, the main goal of this study is to determine to what extent the relationship between urbanization and start-up activity differs depending on the settlement patterns present. The study considers the Netherlands, Sweden, and Belgium as these three countries offer distinct geographies and settlement structures in which potential differences should become visible. The OECD (2008) sees Belgium and the Netherlands as special cases in Europe with high urbanization rates and very dense population structures. Rural regions are always relatively close to urban regions in geographical terms. Sweden is a clear opposite in this respect. At the same time, the countries are relatively similar in their institutional environments (Koopmans 2010; Balcerzak and Pietrzak 2017).

\section{Theoretical framework}

\subsection{Entrepreneurship as an urban event}

Although the empirical evidence on the role of urbanization in start-up patterns is ambiguous, theory expects a positive effect of urbanization on start-up activity (Wagner and Sternberg 2004; Bosma et al. 2008; Baptista and Mendonça 2010). Densely populated regions offer agglomeration advantages that increase the expected mean returns to entrepreneurship. These urbanization economies increase the opportunities for new firm formation by offering a large and differentiated consumer market and providing easy access to specialized inputs and services and qualified labor (Stam 2009; Delfmann et al. 2014; Bosma and Sternberg 2014; Audretsch et al. 2015). Furthermore, new firm formation is an innovative process (Kirchhoff et al. 2007; Baptista et al. 2008), and much of the knowledge relevant in innovation processes is tacit and requires face-toface contacts, facilitated by urban areas (Andersson and Karlsson 2004, 2007; Shearmur 2011). In addition, 
cities offer more opportunities for serendipitous meetings, increasing the likelihood of new collaborations (Stam 2009). Also, the diverse industry mix in large cities increases the prospects for recombination of ideas across different industries (Frenken and Boschma 2007). Assuming that more opportunities for recombination are reflected in higher start-up rates, this would contribute to a positive relationship between urbanization and new firm formation. In addition, the risk of starting a new firm in a large city is considered relatively low as cities provide rich employment opportunities that can function as a safeguard in case the new firm fails (Stam 2009). Finally, skilled and entrepreneurial individuals tend to live in urban areas (Glaeser et al. 2010; Duranton 2014; Westlund et al. 2014).

All the above stimulates start-up activity in cities as it makes entrepreneurship a more attractive choice for locals while also attracting outsiders. Most people start their business close to where they live or have worked (Michelacci and Silva 2007; Dahl and Sorenson 2012; Sternberg 2011), and non-home location choices are strongly driven by urbanization economies (Figueiredo et al. 2002). There is a downside to high levels of urbanization as well. Competition for labor is steep, and wages are relatively high as well as land prices and rents. Particularly for new, small firms that do not yet know their competitive power high upfront costs can deter new firm formation in urban areas (Bosma et al. 2008; Meijers et al. 2016). Reflecting the negatives of agglomeration, Frenken and Boschma (2007) argue that the relationship between urbanization and innovation is not endlessly positive: a "ceiling" will be reached when the positive feedback processes are offset by negative feedback processes. Negative effects of too high levels of urbanization can also run through the housing market. Congestion and high property prices may deter entrepreneurs from choosing the urban centers as their place of residence, driving them to surrounding regions. It is therefore important to take into consideration the wider spatial context: a large city in a densely populated country can have lower startup rates than surrounding regions, as these surrounding regions have a large enough population base to support positive urbanization economies without the negative effects of very high levels of urbanization found in the city. This appears to be the case in the Netherlands, where intermediate regions are gaining entrepreneurs over the most urbanized regions (Van Stel and Suddle 2008; Delfmann et al. 2014).

\subsection{Borrowed size}

The location of a region with respect to (other) key concentrations of population can also be an important mediating effect in the relationship between urbanization and start-up rates. For instance, Shearmur (2011) argues that local variations in the propensity to innovate may be attributable to a region's accessibility to concentrations of activity rather than to local factor endowments. Regions may not be more entrepreneurial because of local characteristics, but because of their better access to major urban centers (Shearmur 2011). Similarly, Andersson and Karlsson (2004) argue that regional innovativeness importantly depends on how easily knowledge is exchanged within the region and on the speed at which new knowledge from other regions is introduced. Though a sparsely populated rural region may have limited ability to exchange knowledge within the region, it can still be relatively conducive for start-up activity if it has a good accessibility to other-urbanregions. A high accessibility adds routines for recombination to a region, resulting in opportunities for innovation. A sparsely populated area located near a major urbanized area can therefore experience relatively high start-up rates, while a city located in a peripheral region and with bad connections to other cities can have relatively low start-up rates.

The concept of "borrowed size" was originally developed by Alonso (1973), in the context of smaller cities borrowing urbanization benefits of their larger neighbors (Meijers and Burger 2015; Meijers et al. 2016). Similarly, rural areas can benefit from nearby urban areas. ${ }^{2}$ Getting access to the functions and networks of large cities can lead to higher average urbanization benefits in nearby areas, even though these functions are not present locally (Camagni et al. 2015). Meijers and Burger (2015) term this "borrowed performance." The distance of a given area from an urban center determines the relative access to these urbanization benefits (Partridge et al. 2007). Rural areas within daily commuting distance can benefit from urban proximity when urban growth spreads to the hinterlands (Partridge et al. 2007). For example, urban growth can spill over to the surrounding regions when firms relocate

\footnotetext{
$\overline{2}$ This can however be reduced to a simple empirical issue as borrowed size actually results from the mismatch between administrative spatial units and functional regions. Hence, urbanization economies may well reach beyond the geographical borders of an administrative spatial unit (Anselin et al. 2000).
} 
to rural areas to take advantage of lower land and labor costs. Also, a growing urban population represents an expanding market for firms located in the exurban fringe (Partridge et al. 2007). Positive effects of good accessibility to urban areas are, however, not a given. Small cities and rural areas can also face spatial competition effects from proximity to a large urban center (Meijers et al. 2016). Urbanization benefits raise the efficiency of firms located in the urban center, making it harder for firms in surrounding areas to compete (Verheul et al. 2002). Indeed, New Economic Geography predicts a shadow effect meaning that competition effects limit the growth of areas near large cities (Burger et al. 2015).

In the end, the net effect of access to other-urbanplaces is an empirical issue that depends on whether the competition shadow is offset by positive urban spillovers (Partridge et al. 2009). The positive effects of borrowed size depend on access to resources for production and potential demand. Particularly, access to knowledge and employees is importantly mediated by distance and its positive effects attenuate rapidly with distance. The competition shadow primarily concerns market competition and access to products attenuates much less rapidly with distance. Therefore, we hypothesize that, all else equal, positive effects from urban centers spread to the areas closest to an urban center, while negative effects prevail beyond the maximum daily commuting distance. Yet, there can also be a "distance-protection" effect as there may be a point at which greater distance insulates the sparsely populated area from urban competition (Polèse and Shearmur 2004). For example, a basic retail store may be better able to support a remote community beyond a certain distance from an urban center (Delfmann et al. 2014).

Thus, the location of a region relative to other population concentrations is likely to have an important mediating impact on the general relationship between urbanization and start-up intensity. Moreover, it is likely that the general level of urbanization and overall settlement pattern in a country further impact this relationship. In sparsely populated countries with a small number of cities, there are many areas that are located too far away from any urban center to benefit from urban spillovers; while in highly urbanized countries, most areas are affected by some urban center (Partridge et al. 2007). In highly urbanized countries, entrepreneurs may therefore be more likely to start a business in more rural areas, as urbanization economies are often within close reach. Also, in a very densely populated country, the urban center may not be the most attractive place to start a new firm due to agglomeration disadvantages. Furthermore, in small countries, the national market can be reached relatively easily from each location.

\section{Empirical strategy}

The empirical analysis aims at identifying the influence of the geography of settlements of a country, in terms of access to cities and the level of urbanization, on the spatial patterns of start-up intensity.

To ensure a variation in the settlement patterns, the analyses focus on three European countries: Belgium, the Netherlands, and Sweden. These countries are interesting cases as they are quite similar in terms of institutions and culture ${ }^{3}$ (Koopmans 2010; Balcerzak and Pietrzak 2017), but they represent distinct national settlement patterns: the Netherlands and Belgium are among the most urbanized and densely populated countries of the OECD, while Sweden is a clear opposite. Performing the analysis for the three countries enables us to assess whether access to cities has a "generic" mediating effect or that it differs dependent on the geography of settlements in these countries.

The spatial patterns in start-up intensity are captured by the rate of new firm formation, which is the dependent variable in all analyses. The start-up rates are calculated using the labor market approach, and the potential municipal workforce is the denominator for standardizing the number of new firm formations (Audretsch and Fritsch 1994). To avoid yearly outliers, the mean start-up rates from 2008 to 2013 are used. The spatial unit of analysis is the municipality. This low level of aggregation is appropriate as new firm formation is a local phenomenon (Sternberg 2011; Audretsch et al. 2015). Indeed, most entrepreneurs start their business close to where they live (Figueiredo et al. 2002; Michelacci and Silva 2007; Stam 2009; Dahl and Sorenson 2012), and a sizeable share of all start-ups operate from home (Mason et al. 2011). Hence, it is plausible to assume that entrepreneurs are mostly influenced by local conditions. The analyses include all municipalities based on 2013 administrative divisions.

\footnotetext{
${ }^{3}$ As it could be argued that Belgium is a special case due to institutional differences between Flanders and Wallonia, we also include a robustness check where we exclude Wallonia from the analyses.
} 
We adopt two regression models that are estimated with a maximum likelihood estimation (MLE). MLE provides a good alternative to estimation by ordinary least squares (OLS) which causes standard errors to be inconsistent for models including spatially lagged explanatory variables (Gibbons and Overman 2012). Alternatively, an instrumental variable (IV) approach could have been appropriate; however, the efficiency of these estimates depends crucially on the choice of the instruments (Anselin and Bera 1998). Hence, as the assumption of normality is met by the data, maximum likelihood is a logical choice. The first model relates start-up rates to the level of urbanization without controlling for settlement patterns and access to urban areas. The second adds controls for the settlement patterns. By analyzing the differences in the two models, it is possible to distill the mediating effect of the settlement patterns on the relationship between urbanization and startup activity.

\subsection{Measuring the mediating effects of settlement patterns}

The level of urbanization is the main explanatory variable of interest. Population density is used as a proxy for urbanization (see also Verheul et al. 2002; Delfmann et al. 2014; Freire-Gibb and Nielsen 2014; Audretsch et al. 2015). Freire-Gibb and Nielsen (2014) argue that "density is one of the key factors in the suitability of urban areas for entrepreneurship" (p. 141). However, as it is expected that the effect of urbanization on start-up activity is mediated by a country's level of urbanization and settlement patterns, we control for this in two ways.

First, we include a spatially lagged variable measuring the average level of urbanization - as measured by population density - in the surrounding municipalities. This variable is included to control for the regional context. If an urban municipality is located in a densely populated region, this may negatively impact the effect of a municipality's own level of urbanization on start-up activity, as the region and city is closer to the "density threshold" (Frenken and Boschma 2007). Cities in the Netherlands and Belgium may be particularly sensitive to this. Sparsely populated municipalities, in contrast, can benefit from being surrounded by more densely populated municipalities in the sense that they can "borrow" urbanization economies from their neighbors. This is likely to be the case in Sweden. The spatially lagged variable of density is calculated using a row- standardized spatial weights matrix based on inverse distances with a cut-off point at $50 \mathrm{~km}$. Hence, it is assumed that closer neighbors have a stronger influence on a municipality and that there is no remaining impact after $50 \mathrm{~km}$. This value is based on commuting distances in the Netherlands, Belgium, and Sweden, as most entrepreneurs start a new firm close to where they work or live (Figueiredo et al. 2002; Michelacci and Silva 2007; Dahl and Sorenson 2012). The value of $50 \mathrm{~km}$ ensures that $90 \%$ of all commuting travels are included (Sandow 2008; Verhetsel et al. 2009; Statistics Netherlands 2016). Since international borders still greatly reduce the intensity of spatial interactions (Pumain 2006), only neighboring municipalities in the same country are considered as neighbors.

Next, to assess the impact of proximity and location in the urban system on the relationship between urbanization and start-up rates, the distance of a municipality to the nearest urban municipality, as well as to successively higher-tiered urban centers, is included in the analysis. First, we measure distance from the geographical centroid of the municipality to the centroid of the nearest urban municipality. If a municipality is located close to a major urban center, it may benefit from urban spillovers as well as "borrowed size" effects (Partridge et al. 2008; Meijers and Burger 2015). If a municipality is classified as urban, the distance to the nearest urban municipality is zero for this municipality. Following Partridge et al. (2008), it can be expected that there is an incremental distance penalty for access to more populous higher-level urban areas. Specifically, remoteness from a larger city would carry an added penalty, but this penalty is only incrementally greater than the already existing distance penalty. Hence, the second distance variable represents the incremental distance to the nearest urban municipality of at least 50,000 inhabitants. This is the distance to the nearest urban municipality of at least 50,000 inhabitants minus the distance to the nearest urban municipality. If the nearest urban municipality has 50,000 or more inhabitants, this variable takes a value of zero. The third and fourth distance variables represent the incremental distances to an urban municipality of at least 100,000 and 250,000 inhabitants, respectively. To assess a possible "distanceprotection" effect, the distances are also squared in the analyses.

Municipalities are defined as urban using the classification of Eurostat. A municipality is considered urban if $50 \%$ or more of the population lives in a high-density 
cluster, which are defined as contiguous grid cells of $1 \mathrm{~km}^{2}$ with a density of at least 1500 inhabitants per square kilometer and a minimum population of 50,000 in total (Dijkstra and Poelman 2012). ${ }^{4}$ The cut-off points for the four urban tiers follow the OECD-EC definition (Dijkstra and Poelman 2012). The distances are calculated as Euclidean distances. Although there may be measurement error bias when using straight-line distance rather than travel time, Apparicio et al. (2008) show that Cartesian distances-i.e., Euclidean and Manhattan distances - are strongly correlated with more accurate travel time distances. Moreover, Partridge et al. (2008) argue that such measurement error would bias the distance regression coefficient toward zero, suggesting that the actual effect of distance would be stronger than reported. Also, with the relatively well-developed road systems in the countries under consideration, the measurement error is expected to be small.

\section{Control variables}

The control variables in the models account for alternative explanations for regional rates. We use the so-called eclectic theory as our frame of reference (Verheul et al. 2002). This approach says that regional start-up rates can be grouped into three broad categories: demand factors, supply factors, and institutions (see also Sternberg 2011). To avoid multicollinearity issues, we focus on the main factors in each broad category.

The demand side entails the opportunities for entrepreneurship created by the market demand for goods and services (Verheul et al. 2002). A key element in this is the industry structure, and we include the share of services as a control variable. A high degree of services is generally positively related to new firm formation due to the lower average start-up costs (Delfmann et al. 2014). Regional unemployment is also an important demand side variable though its impact is ambiguous, and it also affects the supply side of entrepreneurship (Verheul et al. 2002). A high unemployment rate may indicate a weak economy and therefore limited opportunities for entrepreneurship on the demand side. However, if unemployment is high, more persons may be

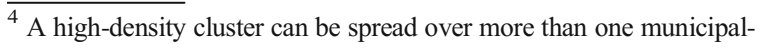
ity, so it can occur that a municipality is considered as urban even though it has less than 50,000 people living within its administrative borders.
}

driven into self-employment as job opportunities are scarce, raising the supply of entrepreneurs.

The supply side is further influenced by the characteristics of the population, i.e., the demographic composition (Verheul et al. 2002). One important demographic determinant for the regional level of new firm formation is the age distribution in a region. Cowling (2000) finds that in most European countries, entrepreneurs are between 41 to 45 years. In the Netherlands, entrepreneurs are slightly younger in average (36-40 years); while in Sweden, they are older ( $>45$ years). To capture this variation, the $35-$ 50 age group is used as a reference category. Following Wagner and Sternberg (2004), we expect an inverted "U"-shape relation between age and the rate of new firm formation. Age is a proxy for personal wealth as older persons have had more time to accumulate wealth, which enables them to invest from their own resources. Also, young families with children may be reluctant to take on the risk of starting a new firm (Delfmann et al. 2014). This suggests a positive relationship between average age and startup intensity. The positive effect may be offset by a negative effect with age as the career time to earn back sunk costs involved in starting a new business is relatively short for older ages. In addition to age, we control for the education level of the population and share of immigrants as both are found to be positively related to new firm formation (Armington and Acs 2002; Acs and Szerb 2007). Higher educated people generally have better resources to start a firm, and immigrants are on average less risk-averse, making them more inclined to start a business (Delfmann et al. 2014).

The institutional environment influences entrepreneurship mainly through the supply side as it influences individual attitudes toward entrepreneurship (Verheul et al. 2002). Most official institutions, such as bankruptcy laws and property rights, are similar in the three countries (Koopmans 2010; Balcerzak and Pietrzak 2017). We therefore focus on the "soft" side of the institutional environment - the entrepreneurial culture. These "soft" institutions are difficult to measure in practice (Aidis et al. 2012; Andersson and Koster 2011). Following Delfmann et al. (2014), we use the share of the public sector in a region as a proxy for entrepreneurial culture. A large governmental sector is assumed to negatively impact new firm formation (Nyström 2008; Aidis et al. 2012). 


\section{Data}

The three national statistics offices offer the data for the explanatory variables. For Belgium, the national statistics office also provides the data on the dependent variable new firm formations. For the Netherlands, start-up data is provided by the Chambers of Commerce that handles the registration of firm units. In Sweden, start-up data is provided by the Swedish Agency for Growth Policy Analysis. Although the data on start-ups come from different sources, the availability of general guidelines provided by Eurostat contributes to a harmonized and synchronized data collection in the European Union (Audretsch et al. 2015), ensuring relatively good comparability between different national data sources. Also, we study within country regional differences in start-up intensities and there is no prior indication that there is an important regional bias in the collection method across the countries. Relocations are excluded, but there is no distinction possible between new establishments of existing firms and genuinely new firms. Although motivations might be different for new subsidiaries or genuinely new firms (Van Oort and Stam 2009; Koster 2007), it is likely that both types of new firm formations are influenced by urbanization and urban proximity as these areas provide the largest consumer markets (Stam 2009; Bosma and Sternberg 2014; Audretsch et al. 2015). Also, Andersson et al. (2016) show that the composition of start-ups in terms of motivation for starting the firm-necessity vs. opportunity-does not vary markedly along the urban-rural hierarchy.

\section{Descriptive analysis}

Table 1 provides summary statistics for the variables used. The statistics regarding start-up rates, population density, and the "distance to urban municipalities" are particularly relevant. The descriptive statistics illustrate the ambiguous relationship between density and start-ups. The Netherlands is the most densely populated country, and it has the highest average start-up rate. Belgium, however, despite its higher density, has a lower average start-up rate than Sweden. Demographic and economic differences may explain part of this, though the descriptive statistics show no clear differences. Hence, the Swedish population may be simply more entrepreneurial. Results from the Global Entrepreneurship Monitor (Kelley et al. 2016) also point to this, and perceived opportunities and capabilities of entrepreneurs are higher in Sweden than in Belgium while the fear of failure is lower.

In terms of access to urban centers, the Netherlands and Belgium are quite similar with Sweden being the clear outlier. In Sweden, the average distance from a municipality to the nearest urban municipality is much greater than in Belgium and the Netherlands. In fact, on average, the distance to the nearest urban municipality of any size is larger than the distance to the largest urban municipalities in the Netherlands or Belgium. There are also fewer small cities in Sweden, as indicated by the low values for the average incremental distance to the nearest urban municipality of at least 50,000 or 100,000 inhabitants. Although these average incremental distances are also low in the Netherlands and Belgium, this is caused by the fact that urban municipalities are located quite close to each other reflecting the high level of urbanization and the small sizes of the countries (OECD, 2008).

Figure 1 shows start-up rates by degree of urbanization for the municipalities in the three countries. Given the differences in geography between the north and the south of Sweden, they are indicated separately. As expected, the correlation between urbanization and startup rates is positive (0.31). There are, however, interesting differences between the countries. For Sweden, the correlation is 0.44 , which is the highest of the three countries. This correlation is even higher when only the south of Sweden is considered (0.60). For the Netherlands and Belgium, the correlation is much weaker, 0.26 and 0.11 , respectively. The flatter distributions of these countries imply that there are relatively good opportunities for start-up activity in the whole country. It suggests that the settlement patterns shape the relation between urbanization and start-up patterns. Sweden and the Netherlands appear to occupy different positions in the same distribution, while Belgium has an on average much lower start-up rate given its regional density levels.

The bivariate positive relationship between density and start-up contrasts earlier findings for the Netherlands that indicated a negative effect (Van Stel and Suddle 2008; Delfmann et al. 2014). Clearly, the bivariate analysis needs to be extended to 
Table 1 Descriptive statistics

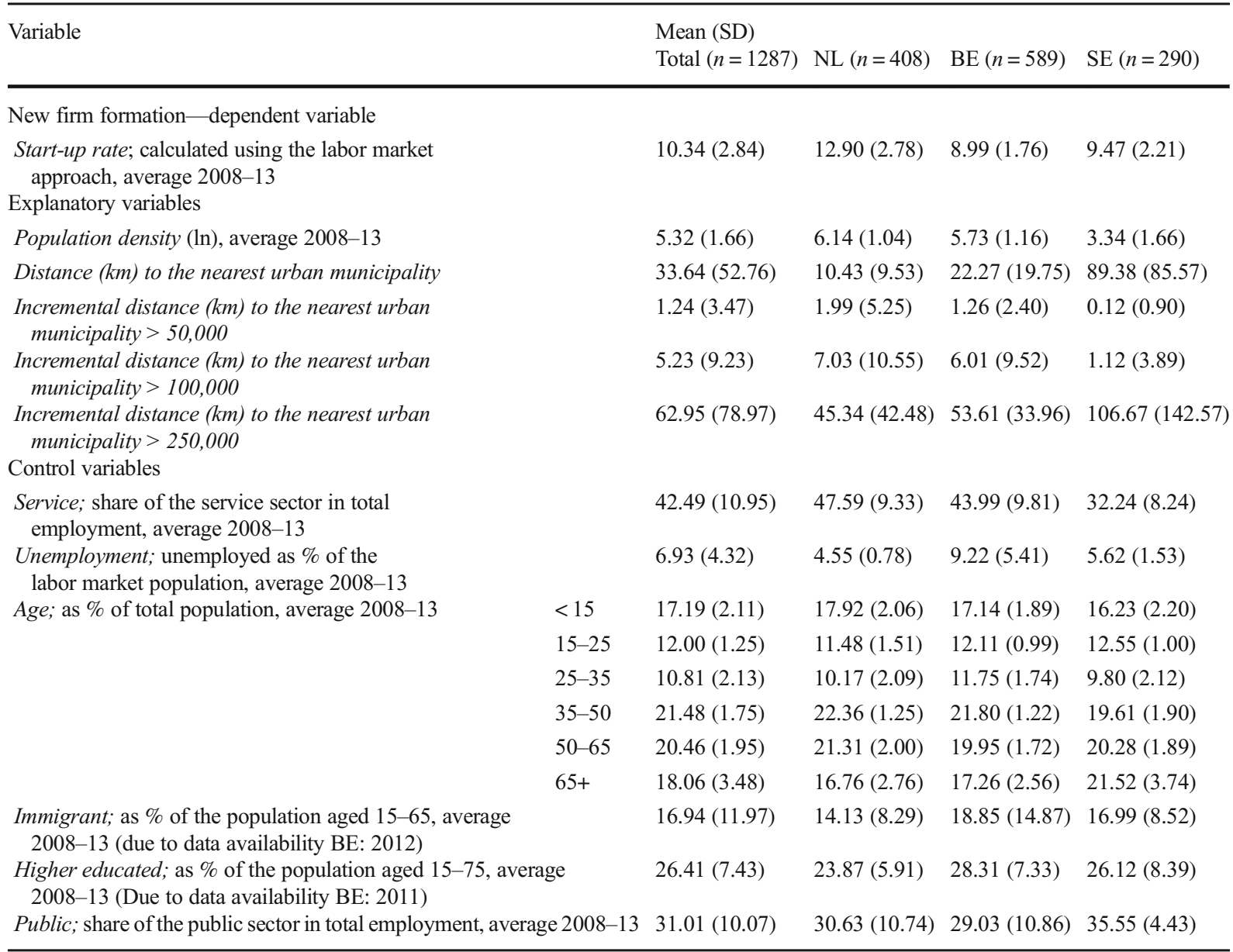

Fig. 1 Start-up rates by degree of urbanization (as measured by population density)

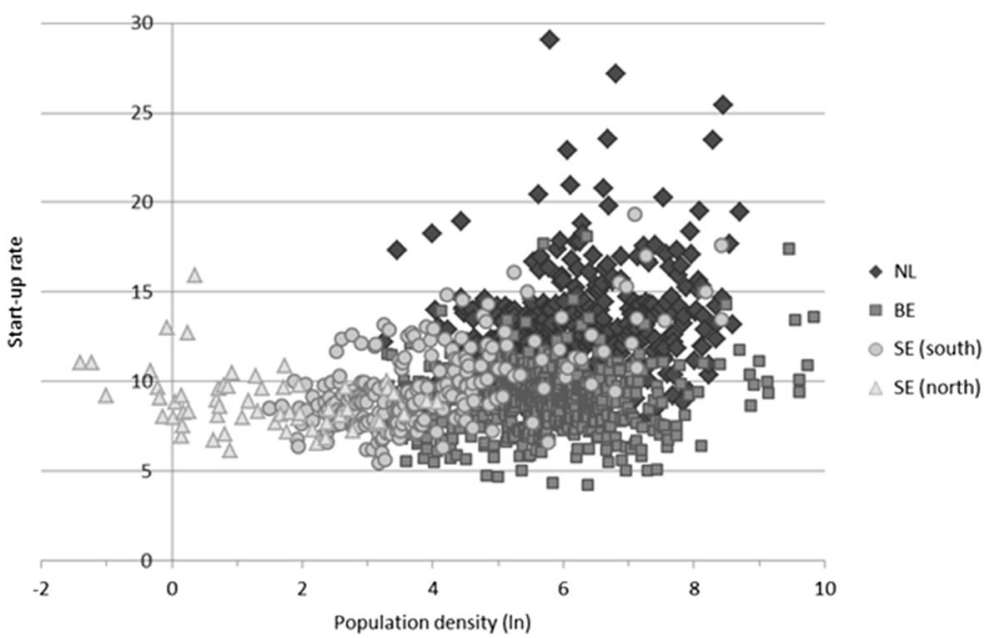


include possible confounding factors and selective sorting into urban areas. This may also account for the relative low start-up levels in Belgium. The figure also hints at the role of access to urban centers as mediating factors in explaining start-up rates. Particularly in the Netherlands, there are some clear outliers: some more intermediate municipalities have higher start-up rates than the most urbanized municipalities possibly resulting from easy access to larger urban areas. Such outliers are less clear in Sweden; although in the north of Sweden, there are some very sparsely populated municipalities that have relatively high start-up rates. This could suggest a positive "splendid isolation" effect as the regions are shielded from outside competition. Alternatively, there may be a measurement bias as municipalities in the north of Sweden are large in area, which cause them to have very low population densities, whereas the population lives concentrated in one part of the municipality. The effect of density may thus be understated. To account for this, we will perform an alternative version of the subsequent regression analyses in which the north of Sweden has been excluded (Section 8, Appendix IV).

\section{Regression analyses}

Table 2 presents two models of start-up rates as a function of a series of explanatory variables for the three countries: the first model does not control for geography while the second model includes the spatially lagged urbanization variable and the distance to urban centers. This section first discusses the estimation results in general (model 1) and the differences between the countries before turning to the relative geography variables and how their inclusion influences the results (model 2).

The results of the first model indicate that in the Netherlands and Belgium, there is a negative effect of urbanization on start-up activity after controlling for other regional characteristics such as income and the share of higher educated people. The positive effect found in the bivariate analysis (Fig. 1) seems to be caused by selective sorting into cities and the economic characteristics of the cities as represented in the control variables. In the Swedish case, the effect of urbanization on start-up activity is not significant after controlling for additional municipal characteristics. This can be explained by the idea that particularly in Sweden, the geography influences the potential of spillovers. Compared to the most urbanized municipalities, start-up rates may be higher in more sparsely populated municipalities relatively close to the urban centers due to specific local characteristics in combination with positive urban spillovers. At the same time, sparsely populated municipalities located at a large distance from any urban center are likely to have lower start-up rates than the most urbanized municipalities. In the Netherlands and Belgium, these contradictory forces are likely to be much weaker, as most municipalities are located close to an urban center. After controlling for access to urban centers (model 2), the effect of own urbanization on start-up intensity should converge between the three countries.

The results for the control variables are mostly in line with previous findings. Only the inverted "U"shaped relationship of age, as hypothesized by Wagner and Sternberg (2004), is not supported by our results. Moreover, the effect of age structure on startup dynamics differs across the countries. In the Netherlands, regions with relatively large shares of the population outside the labor force (younger than 15 and older than 65) have relatively higher start-up intensities. This suggests that differences in demand structure may be driving this result rather than the supply of business owners. Alternatively, young families with children may be more inclined to start a business to benefit from the flexibility it offers (Delfmann et al. 2014). In Belgium, the effect of the share of 15-25- and 25-35-year-olds is significantly positive, implying that with respect to the share of 35-50-year-olds, municipalities with a younger population are more conducive for start-up activity. Moreover, whereas the effect of the share of 5065-year-olds is significantly negative - though only weakly so - the effect of the share of the population aged over 65 is again significantly positive. In Sweden, and in line with Petterson et al. (2010), there is a positive effect of the 50-65-year-olds on start-up activity, as compared with the reference category. For the older ages, entrepreneurship can offer a form of partial retirement, as self-employment offers greater flexibility to accommodate tastes for leisure (Quinn 1980). Moreover, the increasing importance of Internet-based service firms operating from home, with relatively little start-up costs, allows one to earn 
Table 2 Regression results: maximum likelihood estimation for the Netherlands (NL), Belgium (BE), and Sweden (SE)

\begin{tabular}{|c|c|c|c|c|c|c|}
\hline \multirow[t]{2}{*}{ Dependent variable: start-up rate } & \multicolumn{2}{|l|}{ NL } & \multicolumn{2}{|l|}{$\mathrm{BE}$} & \multicolumn{2}{|l|}{$\mathrm{SE}$} \\
\hline & Model 1 & Model 2 & Model 1 & Model 2 & Model 1 & Model 2 \\
\hline Population density (ln) & $\begin{array}{l}-0.386^{* * *} \\
(0.146)\end{array}$ & $\begin{array}{l}-0.503^{* * * *} \\
(0.162)\end{array}$ & $\begin{array}{l}-0.211 * * * \\
(0.0679)\end{array}$ & $\begin{array}{l}-0.514^{* * * *} \\
(0.109)\end{array}$ & $\begin{array}{l}-0.0499 \\
(0.0880)\end{array}$ & $\begin{array}{l}-0.593^{* * * *} \\
(0.109)\end{array}$ \\
\hline Spatial lag population density & & $\begin{array}{l}-0.00221^{* * *} \\
(0.000453)\end{array}$ & & $\begin{array}{l}0.000167 \\
(0.000117)\end{array}$ & & $\begin{array}{l}0.00141^{* * *} \\
(0.000446)\end{array}$ \\
\hline Dist to nearest UC & & $\begin{array}{l}-0.0683^{* * * *} \\
(0.0211)\end{array}$ & & $\begin{array}{l}-0.000344 \\
(0.00768)\end{array}$ & & $\begin{array}{l}-0.00802^{* * * *} \\
(0.00164)\end{array}$ \\
\hline Square of dist to nearest UC & & $\begin{array}{l}0.00174 * \\
(0.000927)\end{array}$ & & $\begin{array}{l}-0.000377^{* * *} \\
(0.000109)\end{array}$ & & $\begin{array}{l}3.90 \mathrm{e}-05^{* * *} \\
(7.31 \mathrm{e}-06)\end{array}$ \\
\hline Inc Dist to UC $>50,000$ & & $\begin{array}{l}-0.178 * * * \\
(0.0390)\end{array}$ & & $\begin{array}{l}0.00520 \\
(0.0622)\end{array}$ & & $\begin{array}{l}0.266 \\
(0.265)\end{array}$ \\
\hline Square of Inc Dist to UC $>50,000$ & & $\begin{array}{l}0.00198 * \\
(0.00110)\end{array}$ & & $\begin{array}{l}0.0189 \\
(0.0131)\end{array}$ & & $\begin{array}{l}-0.0214 \\
(0.0306)\end{array}$ \\
\hline Inc Dist to UC $>100,000$ & & $\begin{array}{l}-0.0630^{* * * *} \\
(0.0167)\end{array}$ & & $\begin{array}{l}-0.0127 \\
(0.0117)\end{array}$ & & $\begin{array}{l}0.00401 \\
(0.0684)\end{array}$ \\
\hline Square of Inc Dist to UC $>100,000$ & & $\begin{array}{l}0.000844 \\
(0.000587)\end{array}$ & & $\begin{array}{l}-0.000647 \\
(0.000560)\end{array}$ & & $\begin{array}{l}0.000617 \\
(0.00343)\end{array}$ \\
\hline Inc Dist to UC $>250,000$ & & $\begin{array}{l}-0.0379 * * * \\
(0.00534)\end{array}$ & & $\begin{array}{l}-0.00855^{* * *} \\
(0.00307)\end{array}$ & & $\begin{array}{l}-0.0111^{* * *} \\
(0.00133)\end{array}$ \\
\hline Square of Inc Dist to UC $>250,000$ & & $\begin{array}{l}0.000124 * \\
(6.45 \mathrm{e}-05)\end{array}$ & & $\begin{array}{l}-0.000107^{*} \\
(5.78 \mathrm{e}-05)\end{array}$ & & $\begin{array}{l}1.57 \mathrm{e}-05^{* * *} \\
(3.54 \mathrm{e}-06)\end{array}$ \\
\hline Age $<15$ & $\begin{array}{l}0.348^{* *} \\
(0.140)\end{array}$ & $\begin{array}{l}0.265^{* *} \\
(0.130)\end{array}$ & $\begin{array}{l}-0.297 * * * \\
(0.0949)\end{array}$ & $\begin{array}{l}-0.125 \\
(0.0905)\end{array}$ & $\begin{array}{l}0.0925 \\
(0.166)\end{array}$ & $\begin{array}{l}0.170 \\
(0.140)\end{array}$ \\
\hline Age $15-25$ & $\begin{array}{l}-0.0942 \\
(0.114)\end{array}$ & $\begin{array}{l}-0.0847 \\
(0.106)\end{array}$ & $\begin{array}{l}0.252 * * * \\
(0.0784)\end{array}$ & $\begin{array}{l}0.374 * * * \\
(0.0785)\end{array}$ & $\begin{array}{l}-0.120 \\
(0.137)\end{array}$ & $\begin{array}{l}0.0131 \\
(0.121)\end{array}$ \\
\hline Age $25-35$ & $\begin{array}{l}-0.0440 \\
(0.137)\end{array}$ & $\begin{array}{l}-0.0110 \\
(0.131)\end{array}$ & $\begin{array}{l}0.277 * * * \\
(0.0850)\end{array}$ & $\begin{array}{l}0.412 * * * \\
(0.0800)\end{array}$ & $\begin{array}{l}-0.0450 \\
(0.119)\end{array}$ & $\begin{array}{l}0.184 * \\
(0.102)\end{array}$ \\
\hline Age $35-50$ & Reference & Reference & Reference & Reference & Reference & Reference \\
\hline Age $50-65$ & $\begin{array}{l}-0.201 \\
(0.151)\end{array}$ & $\begin{array}{l}-0.129 \\
(0.139)\end{array}$ & $\begin{array}{l}-0.153^{*} \\
(0.0901)\end{array}$ & $\begin{array}{l}-0.110 \\
(0.0856)\end{array}$ & $\begin{array}{l}0.439 * * * \\
(0.130)\end{array}$ & $\begin{array}{l}0.458 * * * \\
(0.108)\end{array}$ \\
\hline Age $65+$ & $\begin{array}{l}0.152^{*} \\
(0.0916)\end{array}$ & $\begin{array}{l}0.268^{* * * *} \\
(0.0859)\end{array}$ & $\begin{array}{l}0.121 * * \\
(0.0580)\end{array}$ & $\begin{array}{l}0.273 * * * \\
(0.0572)\end{array}$ & $\begin{array}{l}0.0439 \\
(0.102)\end{array}$ & $\begin{array}{l}0.201 * * \\
(0.0869)\end{array}$ \\
\hline Higher educated & $\begin{array}{l}0.200^{* * * *} \\
(0.0219)\end{array}$ & $\begin{array}{l}0.153^{* * *} \\
(0.0216)\end{array}$ & $\begin{array}{l}0.131^{* * *} \\
(0.0103)\end{array}$ & $\begin{array}{l}0.132 * * * \\
(0.0107)\end{array}$ & $\begin{array}{l}0.0861^{* * *} \\
(0.0215)\end{array}$ & $\begin{array}{l}0.111 * * * \\
(0.0190)\end{array}$ \\
\hline Immigrant & $\begin{array}{l}0.0968^{* * * *} \\
(0.0219)\end{array}$ & $\begin{array}{l}0.0975^{* * * *} \\
(0.0206)\end{array}$ & $\begin{array}{l}-0.000650 \\
(0.00385)\end{array}$ & $\begin{array}{l}0.000304 \\
(0.00362)\end{array}$ & $\begin{array}{l}-0.00335 \\
(0.0141)\end{array}$ & $\begin{array}{l}-0.0289 * * \\
(0.0127)\end{array}$ \\
\hline Unemployment & $\begin{array}{l}0.0978 \\
(0.126)\end{array}$ & $\begin{array}{l}0.131 \\
(0.116)\end{array}$ & $\begin{array}{l}0.0158 \\
(0.0172)\end{array}$ & $\begin{array}{l}0.0350^{*} \\
(0.0185)\end{array}$ & $\begin{array}{l}-0.174 * * * \\
(0.0660)\end{array}$ & $\begin{array}{l}-0.0321 \\
(0.0554)\end{array}$ \\
\hline Service & $\begin{array}{l}0.0884 * * * \\
(0.0173)\end{array}$ & $\begin{array}{l}0.0770^{* * * *} \\
(0.0159)\end{array}$ & $\begin{array}{l}0.00952 \\
(0.00785)\end{array}$ & $\begin{array}{l}0.00444 \\
(0.00753)\end{array}$ & $\begin{array}{l}0.203^{* * * *} \\
(0.0177)\end{array}$ & $\begin{array}{l}0.156 * * * \\
(0.0157)\end{array}$ \\
\hline Public & $\begin{array}{l}0.0128 \\
(0.0154)\end{array}$ & $\begin{array}{l}0.0120 \\
(0.0143)\end{array}$ & $\begin{array}{l}-0.0473^{* * *} \\
(0.00687)\end{array}$ & $\begin{array}{l}-0.0414 * * * \\
(0.00645)\end{array}$ & $\begin{array}{l}-0.0407 \\
(0.0257)\end{array}$ & $\begin{array}{l}-0.0102 \\
(0.0214)\end{array}$ \\
\hline Constant & $\begin{array}{l}-1.227 \\
(8.831)\end{array}$ & $\begin{array}{l}-0.774 \\
(8.138)\end{array}$ & $\begin{array}{l}5.835 \\
(5.411)\end{array}$ & $\begin{array}{l}-3.760 \\
(5.135)\end{array}$ & $\begin{array}{l}-6.255 \\
(9.063)\end{array}$ & $\begin{array}{l}-16.67 * * \\
(7.642)\end{array}$ \\
\hline Log likelihood & -849.4091 & -808.6055 & -1022.125 & -973.9487 & -485.6899 & -422.6284 \\
\hline
\end{tabular}


Table 2 (continued)

\begin{tabular}{|c|c|c|c|c|c|c|}
\hline \multirow[t]{2}{*}{ Dependent variable: start-up rate } & \multicolumn{2}{|l|}{ NL } & \multicolumn{2}{|l|}{$\mathrm{BE}$} & \multicolumn{2}{|l|}{$\mathrm{SE}$} \\
\hline & Model 1 & Model 2 & Model 1 & Model 2 & Model 1 & Model 2 \\
\hline $\mathrm{AIC}$ & 1724.818 & 1661.211 & 2070.25 & 1991.897 & 997.3799 & 889.2568 \\
\hline Wald $\mathrm{Chi}^{2}$ & $390.33 * * *$ & $567.87 * * *$ & $376.65 * * *$ & $548.27 * * *$ & $558.51 * * *$ & $1020.79 * * *$ \\
\hline Observations & 405 & 405 & 589 & 589 & 290 & 290 \\
\hline
\end{tabular}

Standard errors in parentheses

$* * * p<0.01 ; * * p<0.05 ; * p<0.1$

back investment costs sooner (Colombo and Delmastro 2001), making starting a new firm a feasible career option for older people.

In the second model in Table 2, we enter the relative location of municipalities by including the distance to cities and the lagged urbanization variable. Importantly, the effect of population density - i.e., the level of urbanization - is now significant and negative for all countries and the effects of urbanization are of similar strength. This convergence is consistent with the idea that differences in settlement patterns mediate the effect of urbanization on start-up rates. As such, it provides a likely explanation for ambivalent results in earlier studies that did not explicitly address the relative geography in which cities are located (see, for example, Fritsch and Falck 2007; Bosma et al. 2008; Pettersson et al. 2010; Delfmann et al. 2014; Audretsch et al. 2015). It also suggests that, after controlling for regional characteristics and relative location, the three countries though at different levels are part of the same linear relationship between density and start-up patterns.

The effects of interaction between cities and surrounding regions differ across the three countries. In the Netherlands, the direct effect of the level of urbanization of the neighboring municipalities on start-up activity is negative, suggesting competition effects. Given the overall higher density in the Netherlands, the benefits of urban spillover stemming from density is relatively low and municipalities are more substitutes than complements. In Belgium however, which has a similar level of population density, there is no significant direct effect of the level of urbanization of neighboring municipalities on start-up activity. This might be explained by differences between Flanders and Wallonia: Flanders is similar to the Netherlands in terms of its urbanization level, and it is likely that competition effects are also important here; whereas in the lessurbanized Wallonia, regions can be more complementary. These two opposing forces cancel each other out if Belgium is considered as a whole. To correct for this, we have performed a robustness check in which Wallonia has been excluded, which will be discussed below (Section 8, Appendix III). In Sweden, a municipality is more conducive for start-up activity if positioned in a more densely populated wider region. Swedish start-ups are relatively often located in more urbanized regions, though not in the urban centers.

Distance to urban centers has a negative effect on start-up rates. Furthermore, there is an additional penalty for being removed from larger cities. A municipality does not have to be very densely populated itself to be conducive for start-up activity. Indeed, after controlling for other factors, the effect is negative. Being close to an urban center, preferably a larger one, is beneficial for start-up rates. The squared distance variables are generally positive, implying that there is a point where greater distance from an urban center insulates the municipality from urban competition-i.e., the "distance-protection" effect as noted by Polèse and Shearmur (2004).

Belgium is an outlier, and only the squared distance from the nearest urban center contributes to the explanation of municipal start-up rates. Only municipalities located very far from an urban center are less conducive for start-up activity. The insignificant effects of increasing distance from cities of other sizes can be explained by the fact that the small size of Belgium in combination with its high level of urbanization ensures that rural areas may never experience backwash from any urban center before they encounter positive urban spillovers from another (Partridge et al. 2007). However, for the Netherlands, also a small and highly urbanized country, all urban tiers 
have a significant effect. Differences in the perceptions of population can provide a tentative explanation for this: Belgians may be willing to travel further for work than Dutch people. In that case, urban spillovers also extend over a larger distance. The on-average longer commuting distances in Belgium compared to the Netherlands are in line with this explanation (Verhetsel et al. 2009; Statistics Netherlands 2016).

For Sweden, the distance to the nearest urban center and the incremental distance to the largest urban centers - i.e., those of 250,000 inhabitants or more- have significantly negative effects on start-up activity. This is likely caused by the fact that Sweden hosts fewer smaller urban areas than the Netherlands or Belgium. Often, the nearest urban center in Sweden has 50,000 or 100,000 inhabitants and therefore there is no additional distance penalty. In addition, in Sweden, there is also a "distance-protection" effect for the municipalities located very far from an urban center. Interestingly, this "distance-protection" effect kicks in at a much larger distance in Sweden than in the Netherlands. For example, in the Netherlands, the squared term for distance to the nearest urban center indicates that around the hypothetical distance of $40 \mathrm{~km}$ from an urban center the distance effect becomes positive; whereas for Sweden, this "distanceprotection" effect only starts at about $200 \mathrm{~km}$. Differences in perceptions can again be the key here. What is considered as a long trip in the Netherlands may be less problematic in the Swedish context (Delfmann and Koster 2013; Sandow 2008; Statistics Netherlands 2016).

\section{Robustness checks}

We tested the robustness of the results in several ways. As it can be argued that the cut-off point for the spatial weights matrix used to calculate the spatially lagged urbanization variable is to some extent arbitrary, we reran the regression analyses using spatial lags based on cut-off points of 30,70 , and $100 \mathrm{~km}$. We also performed analyses where we excluded the incremental distances to cities of over 50,000 and over 100,000 inhabitants, as the relatively large number of cases with a value of 0 for these variables could cause problems.
The results (Appendix I and II) hardly deviate from the original model. The effect of access to other cities or borrowed size thus seem robust to the exact cut-off points used. Importantly, also the "own" density effect on the start-up rate remains consistent across the three countries.

Other possible concerns are institutional and geographical differences between Flanders and Wallonia distorting the results for Belgium. Indeed, these institutional differences may cause the significant negative effect of the squared distance to the nearest urban center: those municipalities relatively far from any urban center are generally located in Wallonia, where start-up levels are lower on average. Therefore, we reran the analyses for Belgium excluding Wallonia (Appendix III). We chose not to use a dummy indicating whether a municipality is Flemish or Walloon since we expect that the institutional differences do not only cause a difference in the level of the start-up rate but also in how certain explanatory variables impact the dependent variable. For example, as the urbanization level is much higher in Flanders, the mediating impact of the distance to urban municipalities may differ from that in Wallonia. In Flanders, most municipalities are influenced by some urban center, whereas this is not the case in Wallonia. For Flemish municipalities, only increasing distance from an urban center of at least 100,000 inhabitants have a significant negative effect on start-up activity. In addition, there seems to be a slight "distanceprotection" effect from the largest urban centers, i.e., those of 250,000 inhabitants or more. Excluding Wallonia also turns the spatially lagged urbanization variable significantly negative, confirming our hypothesis that in Flanders, parallel to the Netherlands, competition effects between regions play a role. The larger size and lower population level of municipalities in the north of Sweden could distort the results for Sweden, both by increasing the volatility of the start-up rates and because these municipalities have very low population densities while most of the population concentrates in one relatively densely populated part of the municipality. In addition, the less dense road system in the north of Sweden may cause problems as we use Euclidean distances to calculate the distance to urban centers. To account for this, we excluded the north of Sweden and reran the analyses (Appendix IV). The results remain robust to this slightly different set-up of the model. 


\section{Conclusion}

The goal of this study was to determine whether the relationship between urbanization and start-up activity differs between countries depending on the relative settlement patterns of these countries. Places do not operate in a vacuum, and to understand the effect of "own" density on start-up patterns, we need to account for the urban spillovers or borrowed size that they may experience from other places nearby. This may account for the empirical ambiguity in the relationship between urbanization and start-up intensity. Also, the impact of other places on start-up intensity is relevant in and of itself.

Without controlling for settlement patterns, urbanization has a significant negative effect on startup activity in the Netherlands and Belgium, whereas the effect is insignificant for Sweden. After including a spatially lagged urbanization variable and variables measuring the distance to the urban centers, the effect of urbanization on start-up rates becomes significantly negative in all three countries. Also, it is of the same magnitude. This suggests that empirical effects of urbanization are indeed strongly impacted by the wider geographical context. More specifically for start-up research, it shows that start-up rates may be higher in urban areas but that this is associated with spatial sorting of people and economic activities and not so much with the urbanization economies these areas offer. In fact, after controlling for the supply of entrepreneurs, demand for products and the institutional environment, the benefits of start-up in a dense place (knowledge spillovers, increased potential for new combinations) seem to be outweighed by the additional costs (rents, labor costs).

The effects of spatial spillover or borrowed size are more diffuse across the countries, reflecting the different geographies and overall levels of density. In the Netherlands and Flanders, being surrounded by densely populated neighbors has a negative effect on local start-up activity; whereas in Sweden, the direct effect is positive. Increasing distance from an urban center has a consistent negative effect on start-up rates, and there is an additional penalty for distance from higher-tiered cities. This implies that a municipality does not have to be very highly urbanized itself to be conducive for start-up activity. Access to urban centers, however, is crucial. Yet, at a very large distance from an urban center, greater distance can also protect rural areas as it insulates firms from urban competition. Interestingly, the distance across which urban spillovers are felt differs between the three countries. This is in line with assumed differences in the perception of distance, possibly following from the settlement patterns in countries: People living in a more sparsely populated country such as Sweden are generally willing to commute further than people living in a highly urbanized country such as Belgium or the Netherlands.

This study, however, did not directly address the mechanisms through which the relative location of places influences start-up patterns. The results must thus be taken as stylized facts, and they can be supplemented by studies that consider the mechanisms more directly, for example, by assessing firm location and the geographical markets in which it is active. Also, it is plausible that different types of start-up-service vs. manufacturing, new vs. new branch, and opportunity vs. necessity - are impacted differently by national settlement patterns (Lavesson 2017). And while this explorative study focused on three illustrative countries, it would be interesting to study a wider variety of national settlement patterns.

A rural or urban area in the north of Sweden is not the same as a rural or urban area in the Netherlands or Belgium, or even in the south of Sweden. Logical as this may seem, this study is one of the first to explicitly study the impact of the geographical context on start-up patterns. Accounting for the relative location of places, we find that "own" density has a consistently negative effect on start-up intensity, while the access to other places has a generally positive effect although this is more diffuse. It comes to show that part of the entrepreneurship puzzle local policy makers struggle with lies outside of their control. The results imply that understanding the context in which your city is located may be as important as understanding the city itself. Urbanization economies extend far beyond the borders of local administrative units: the impact of major urban areas is felt over a long distance, and rural areas or smaller cities nearby major cities behave differently from those located in more isolated areas. 


\section{Appendix I}

Table 3 Robustness check: 30-km cut-off

\begin{tabular}{|c|c|c|c|c|c|c|}
\hline \multirow[t]{2}{*}{ Dependent variable: start-up rate } & \multicolumn{2}{|l|}{ NL } & \multicolumn{2}{|l|}{$\mathrm{BE}$} & \multicolumn{2}{|l|}{ SE } \\
\hline & Model 1 & Model 2 & Model 1 & Model 2 & Model 1 & Model 2 \\
\hline \multirow[t]{2}{*}{ Population density (ln) } & $-0.386 * * *$ & $-0.516^{* * *}$ & $-0.211 * * *$ & $-0.531 * * *$ & -0.0499 & $-0.621 * * *$ \\
\hline & $(0.146)$ & $(0.164)$ & $(0.0679)$ & $(0.109)$ & $(0.0880)$ & $(0.111)$ \\
\hline \multirow[t]{2}{*}{ Spatial lag population density } & & $-0.00146^{* * *}$ & & $0.000167 * *$ & & $0.000594^{*}$ \\
\hline & & $(0.000337)$ & & $(7.78 \mathrm{e}-05)$ & & $(0.000352)$ \\
\hline \multirow[t]{2}{*}{ Dist to nearest UC } & & $-0.0609 * * *$ & & 0.000119 & & $-0.00847 * * *$ \\
\hline & & $(0.0210)$ & & $(0.00759)$ & & $(0.00165)$ \\
\hline \multirow[t]{2}{*}{ Square of dist to nearest UC } & & $0.00159 *$ & & $-0.000389 * * *$ & & $3.93 \mathrm{e}-05 * * *$ \\
\hline & & $(0.000929)$ & & $(0.000109)$ & & $(7.42 \mathrm{e}-06)$ \\
\hline \multirow[t]{2}{*}{ Inc Dist to UC $>50,000$} & & $-0.165 * * *$ & & -0.0126 & & $0.452 *$ \\
\hline & & $(0.0388)$ & & $(0.0630)$ & & $(0.260)$ \\
\hline \multirow[t]{2}{*}{ Square of Inc Dist to UC $>50,000$} & & $0.00211 *$ & & 0.0216 & & -0.0393 \\
\hline & & $(0.00110)$ & & $(0.0131)$ & & $(0.0303)$ \\
\hline \multirow[t]{2}{*}{ Inc Dist to UC $>100,000$} & & $-0.0609 * * *$ & & -0.0134 & & 0.0907 \\
\hline & & $(0.0168)$ & & $(0.0116)$ & & $(0.0611)$ \\
\hline \multirow[t]{2}{*}{ Square of Inc Dist to UC $>100,000$} & & $0.00104 *$ & & -0.000600 & & -0.00237 \\
\hline & & $(0.000590)$ & & $(0.000559)$ & & $(0.00328)$ \\
\hline \multirow[t]{2}{*}{ Inc Dist to UC $>250,000$} & & $-0.0309 * * *$ & & $-0.00880 * * *$ & & $-0.0114 * * *$ \\
\hline & & $(0.00456)$ & & $(0.00290)$ & & $(0.00134)$ \\
\hline \multirow[t]{2}{*}{ Square of Inc Dist to UC $>250,000$} & & $8.27 \mathrm{e}-05$ & & $-9.56 \mathrm{e}-05^{*}$ & & $1.65 \mathrm{e}-05 * * *$ \\
\hline & & $(6.21 \mathrm{e}-05)$ & & $(5.81 \mathrm{e}-05)$ & & $(3.57 \mathrm{e}-06)$ \\
\hline \multirow[t]{2}{*}{ Age $<15$} & $0.348 * *$ & $0.302 * *$ & $-0.297 * * *$ & -0.134 & 0.0925 & 0.143 \\
\hline & $(0.140)$ & $(0.131)$ & $(0.0949)$ & $(0.0904)$ & $(0.166)$ & $(0.141)$ \\
\hline \multirow[t]{2}{*}{ Age $15-25$} & -0.0942 & -0.0785 & $0.252 * * *$ & $0.361 * * *$ & -0.120 & -0.0489 \\
\hline & $(0.114)$ & $(0.106)$ & $(0.0784)$ & $(0.0785)$ & $(0.137)$ & $(0.121)$ \\
\hline \multirow[t]{2}{*}{ Age $25-35$} & -0.0440 & 0.0102 & $0.277 * * *$ & $0.403 * * *$ & -0.0450 & $0.194 *$ \\
\hline & $(0.137)$ & $(0.132)$ & $(0.0850)$ & $(0.0799)$ & $(0.119)$ & $(0.103)$ \\
\hline Age $35-50$ & Reference & Reference & Reference & Reference & Reference & Reference \\
\hline \multirow[t]{2}{*}{ Age $50-65$} & -0.201 & -0.114 & $-0.153 *$ & -0.110 & $0.439 * * *$ & $0.446 * * *$ \\
\hline & $(0.151)$ & $(0.140)$ & $(0.0901)$ & $(0.0847)$ & $(0.130)$ & $(0.110)$ \\
\hline \multirow[t]{2}{*}{ Age $65+$} & $0.152 *$ & $0.275^{* * *}$ & $0.121^{* *}$ & $0.264 * * *$ & 0.0439 & $0.182 * *$ \\
\hline & $(0.0916)$ & $(0.0866)$ & $(0.0580)$ & $(0.0572)$ & $(0.102)$ & $(0.0876)$ \\
\hline \multirow[t]{2}{*}{ Higher educated } & $0.200 * * *$ & $0.160 * * *$ & $0.131 * * *$ & $0.131 * * *$ & $0.0861 * * *$ & $0.115 * * *$ \\
\hline & $(0.0219)$ & $(0.0216)$ & $(0.0103)$ & $(0.0107)$ & $(0.0215)$ & $(0.0192)$ \\
\hline \multirow[t]{2}{*}{ Immigrant } & $0.0968 * * *$ & $0.0967 * * *$ & -0.000650 & 0.000380 & -0.00335 & $-0.0283 * *$ \\
\hline & $(0.0219)$ & $(0.0207)$ & $(0.00385)$ & $(0.00361)$ & $(0.0141)$ & $(0.0128)$ \\
\hline \multirow[t]{2}{*}{ Unemployment } & 0.0978 & 0.144 & 0.0158 & $0.0358 * *$ & $-0.174 * * *$ & -0.0226 \\
\hline & $(0.126)$ & $(0.116)$ & $(0.0172)$ & $(0.0182)$ & $(0.0660)$ & $(0.0560)$ \\
\hline \multirow[t]{2}{*}{ Service } & $0.0884 * * *$ & $0.0781 * * *$ & 0.00952 & 0.00343 & $0.203 * * *$ & $0.158 * * *$ \\
\hline & $(0.0173)$ & $(0.0160)$ & $(0.00785)$ & $(0.00749)$ & $(0.0177)$ & $(0.0159)$ \\
\hline Public & 0.0128 & 0.0135 & $-0.0473 * * *$ & $-0.0416^{* * *}$ & -0.0407 & -0.0144 \\
\hline
\end{tabular}


Table 3 (continued)

\begin{tabular}{|c|c|c|c|c|c|c|}
\hline \multirow[t]{2}{*}{ Dependent variable: start-up rate } & \multicolumn{2}{|l|}{ NL } & \multicolumn{2}{|l|}{$\mathrm{BE}$} & \multicolumn{2}{|l|}{ SE } \\
\hline & Model 1 & Model 2 & Model 1 & Model 2 & Model 1 & Model 2 \\
\hline \multirow{3}{*}{ Constant } & $(0.0154)$ & $(0.0144)$ & $(0.00687)$ & $(0.00644)$ & $(0.0257)$ & $(0.0216)$ \\
\hline & -1.227 & -3.036 & 5.835 & -3.145 & -6.255 & $-14.80^{*}$ \\
\hline & $(8.831)$ & $(8.174)$ & $(5.411)$ & $(5.125)$ & $(9.063)$ & $(7.713)$ \\
\hline Log likelihood & -849.4091 & -810.9724 & -1022.125 & -972.6557 & -485.6899 & -426.1328 \\
\hline AIC & 1724.818 & 1665.945 & 2070.25 & 1989.311 & 997.3799 & 896.2655 \\
\hline Wald $\mathrm{Chi}^{2}$ & $390.33^{* * *}$ & $556.57 * * *$ & $376.65 * * *$ & $553.28 * * *$ & $558.51 * * *$ & $989.50 * * *$ \\
\hline Observations & 405 & 405 & 589 & 589 & 290 & 290 \\
\hline
\end{tabular}

Standard errors in parentheses

$* * * p<0.01 ; * * p<0.05 ; * p<0.1$

Table 4 Robustness check: 70-km cut-off

\begin{tabular}{|c|c|c|c|c|c|c|}
\hline \multirow[t]{2}{*}{ Dependent variable: start-up rate } & \multicolumn{2}{|l|}{ NL } & \multicolumn{2}{|l|}{$\mathrm{BE}$} & \multicolumn{2}{|l|}{ SE } \\
\hline & Model 1 & Model 2 & Model 1 & Model 2 & Model 1 & Model 2 \\
\hline Population density (ln) & $\begin{array}{l}-0.386^{* * * *} \\
(0.146)\end{array}$ & $\begin{array}{l}-0.541 * * * \\
(0.164)\end{array}$ & $\begin{array}{l}-0.211 * * * \\
(0.0679)\end{array}$ & $\begin{array}{l}-0.509^{* * *} \\
(0.108)\end{array}$ & $\begin{array}{l}-0.0499 \\
(0.0880)\end{array}$ & $\begin{array}{l}-0.580^{* * *} \\
(0.109)\end{array}$ \\
\hline Spatial lag population density & & $\begin{array}{l}-0.00235^{* * * *} \\
(0.000612)\end{array}$ & & $\begin{array}{l}0.000244 \\
(0.000157)\end{array}$ & & $\begin{array}{l}0.00141 * * * \\
(0.000394)\end{array}$ \\
\hline Dist to nearest UC & & $\begin{array}{l}-0.0653 * * * \\
(0.0219)\end{array}$ & & $\begin{array}{l}0.000435 \\
(0.00776)\end{array}$ & & $\begin{array}{l}-0.00761 * * * \\
(0.00164)\end{array}$ \\
\hline Square of dist to nearest UC & & $\begin{array}{l}0.00154 \\
(0.000935)\end{array}$ & & $\begin{array}{l}-0.000380^{* * *} \\
(0.000109)\end{array}$ & & $\begin{array}{l}3.79 \mathrm{e}-05 * * * \\
(7.29 \mathrm{e}-06)\end{array}$ \\
\hline Inc Dist to UC $>50,000$ & & $\begin{array}{l}-0.165^{* * *} \\
(0.0391)\end{array}$ & & $\begin{array}{l}0.00672 \\
(0.0620)\end{array}$ & & $\begin{array}{l}0.284 \\
(0.257)\end{array}$ \\
\hline Square of Inc Dist to UC $>50,000$ & & $\begin{array}{l}0.00179 \\
(0.00111)\end{array}$ & & $\begin{array}{l}0.0183 \\
(0.0130)\end{array}$ & & $\begin{array}{l}-0.0227 \\
(0.0301)\end{array}$ \\
\hline Inc Dist to UC $>100,000$ & & $\begin{array}{l}-0.0604 * * * \\
(0.0169)\end{array}$ & & $\begin{array}{l}-0.0121 \\
(0.0117)\end{array}$ & & $\begin{array}{l}0.0236 \\
(0.0625)\end{array}$ \\
\hline Square of Inc Dist to UC $>100,000$ & & $\begin{array}{l}0.000826 \\
(0.000594)\end{array}$ & & $\begin{array}{l}-0.000660 \\
(0.000559)\end{array}$ & & $\begin{array}{l}5.52 \mathrm{e}-05 \\
(0.00329)\end{array}$ \\
\hline Inc Dist to UC $>250,000$ & & $\begin{array}{l}-0.0378 * * * \\
(0.00627)\end{array}$ & & $\begin{array}{l}-0.00768 * * \\
(0.00328)\end{array}$ & & $\begin{array}{l}-0.0108^{* * * *} \\
(0.00133)\end{array}$ \\
\hline Square of Inc Dist to UC $>250,000$ & & $\begin{array}{l}0.000104 \\
(6.70 \mathrm{e}-05)\end{array}$ & & $\begin{array}{l}-0.000100 * \\
(5.85 \mathrm{e}-05)\end{array}$ & & $\begin{array}{l}1.53 \mathrm{e}-05^{* * *} \\
(3.54 \mathrm{e}-06)\end{array}$ \\
\hline Age $<15$ & $\begin{array}{l}0.348 * * \\
(0.140)\end{array}$ & $\begin{array}{l}0.263^{* * *} \\
(0.131)\end{array}$ & $\begin{array}{l}-0.297 * * * \\
(0.0949)\end{array}$ & $\begin{array}{l}-0.119 \\
(0.0904)\end{array}$ & $\begin{array}{l}0.0925 \\
(0.166)\end{array}$ & $\begin{array}{l}0.163 \\
(0.139)\end{array}$ \\
\hline Age $15-25$ & $\begin{array}{l}-0.0942 \\
(0.114)\end{array}$ & $\begin{array}{l}-0.0937 \\
(0.107)\end{array}$ & $\begin{array}{l}0.252 * * * \\
(0.0784)\end{array}$ & $\begin{array}{l}0.380 * * * \\
(0.0786)\end{array}$ & $\begin{array}{l}-0.120 \\
(0.137)\end{array}$ & $\begin{array}{l}-0.00603 \\
(0.118)\end{array}$ \\
\hline Age $25-35$ & -0.0440 & 0.00625 & $0.277 * * *$ & $0.414 * * *$ & -0.0450 & $0.178 *$ \\
\hline
\end{tabular}


Table 4 (continued)

\begin{tabular}{|c|c|c|c|c|c|c|}
\hline \multirow[t]{2}{*}{ Dependent variable: start-up rate } & \multicolumn{2}{|l|}{ NL } & \multicolumn{2}{|l|}{$\mathrm{BE}$} & \multicolumn{2}{|l|}{ SE } \\
\hline & Model 1 & Model 2 & Model 1 & Model 2 & Model 1 & Model 2 \\
\hline & $(0.137)$ & $(0.133)$ & $(0.0850)$ & $(0.0800)$ & $(0.119)$ & $(0.101)$ \\
\hline Age $35-50$ & Reference & Reference & Reference & Reference & Reference & Reference \\
\hline \multirow[t]{2}{*}{ Age $50-65$} & -0.201 & -0.140 & $-0.153 *$ & -0.103 & $0.439 * * *$ & $0.452 * * *$ \\
\hline & $(0.151)$ & $(0.140)$ & $(0.0901)$ & $(0.0861)$ & $(0.130)$ & $(0.107)$ \\
\hline \multirow[t]{2}{*}{ Age $65+$} & $0.152 *$ & $0.273 * * *$ & $0.121 * *$ & $0.277 * * *$ & 0.0439 & $0.192 * *$ \\
\hline & $(0.0916)$ & $(0.0871)$ & $(0.0580)$ & $(0.0571)$ & $(0.102)$ & $(0.0862)$ \\
\hline \multirow[t]{2}{*}{ Higher educated } & $0.200 * * *$ & $0.152 * * *$ & $0.131 * * *$ & $0.132 * * *$ & $0.0861 * * *$ & $0.112 * * *$ \\
\hline & $(0.0219)$ & $(0.0219)$ & $(0.0103)$ & $(0.0107)$ & $(0.0215)$ & $(0.0188)$ \\
\hline \multirow[t]{2}{*}{ Immigrant } & $0.0968 * * *$ & $0.0968 * * *$ & -0.000650 & 0.000334 & -0.00335 & $-0.0296^{* *}$ \\
\hline & $(0.0219)$ & $(0.0208)$ & $(0.00385)$ & $(0.00361)$ & $(0.0141)$ & $(0.0126)$ \\
\hline \multirow[t]{2}{*}{ Unemployment } & 0.0978 & 0.134 & 0.0158 & $0.0314 *$ & $-0.174 * * *$ & -0.0317 \\
\hline & $(0.126)$ & $(0.117)$ & $(0.0172)$ & $(0.0191)$ & $(0.0660)$ & $(0.0551)$ \\
\hline \multirow[t]{2}{*}{ Service } & $0.0884 * * *$ & $0.0779 * * *$ & 0.00952 & 0.00448 & $0.203 * * *$ & $0.155 * * *$ \\
\hline & $(0.0173)$ & $(0.0161)$ & $(0.00785)$ & $(0.00749)$ & $(0.0177)$ & $(0.0157)$ \\
\hline \multirow[t]{2}{*}{ Public } & 0.0128 & 0.0129 & $-0.0473 * * *$ & $-0.0417 * * *$ & -0.0407 & -0.0148 \\
\hline & $(0.0154)$ & $(0.0145)$ & $(0.00687)$ & $(0.00646)$ & $(0.0257)$ & $(0.0212)$ \\
\hline \multirow[t]{2}{*}{ Constant } & -1.227 & -0.520 & 5.835 & -4.170 & -6.255 & $-15.71 * *$ \\
\hline & $(8.831)$ & $(8.237)$ & $(5.411)$ & $(5.148)$ & $(9.063)$ & $(7.562)$ \\
\hline Log likelihood & -849.4091 & -812.9258 & -1022.125 & -973.7585 & -485.6899 & -421.3203 \\
\hline AIC & 1724.818 & 1669.852 & 2070.25 & 1991.517 & 997.3799 & 886.6406 \\
\hline Wald $\mathrm{Chi}^{2}$ & $390.33 * * *$ & $547.34 * * *$ & $376.65 * * *$ & $549.01 * * *$ & $558.51 * * *$ & $1032.67 * * *$ \\
\hline Observations & 405 & 405 & 589 & 589 & 290 & 290 \\
\hline
\end{tabular}

Standard errors in parentheses

$* * * p<0.01 ; * * p<0.05 ; * p<0.1$

Table 5 Robustness check: 100-km cut-off

\begin{tabular}{|c|c|c|c|c|c|c|}
\hline \multirow[t]{2}{*}{ Dependent variable: start-up rate } & \multicolumn{2}{|l|}{ NL } & \multicolumn{2}{|l|}{$\mathrm{BE}$} & \multicolumn{2}{|l|}{ SE } \\
\hline & Model 1 & Model 2 & Model 1 & Model 2 & Model 1 & Model 2 \\
\hline Population density (ln) & $\begin{array}{l}-0.386^{* * * *} \\
(0.146)\end{array}$ & $\begin{array}{l}-0.540 * * * \\
(0.162)\end{array}$ & $\begin{array}{l}-0.211 * * * \\
(0.0679)\end{array}$ & $\begin{array}{l}-0.545^{* * *} \\
(0.108)\end{array}$ & $\begin{array}{l}-0.0499 \\
(0.0880)\end{array}$ & $\begin{array}{l}-0.590 * * * \\
(0.110)\end{array}$ \\
\hline Spatial lag population density & & $\begin{array}{l}-0.00344 * * * \\
(0.000750)\end{array}$ & & $\begin{array}{l}0.000624 * * * \\
(0.000186)\end{array}$ & & $\begin{array}{l}0.00137 * * * \\
(0.000452)\end{array}$ \\
\hline Dist to nearest UC & & $\begin{array}{l}-0.0705^{* * *} \\
(0.0216)\end{array}$ & & $\begin{array}{l}0.00306 \\
(0.00763)\end{array}$ & & $\begin{array}{l}-0.00752 * * * \\
(0.00167)\end{array}$ \\
\hline Square of dist to nearest UC & & $\begin{array}{l}0.00154 * \\
(0.000924)\end{array}$ & & $\begin{array}{l}-0.000389^{* * * *} \\
(0.000108)\end{array}$ & & $\begin{array}{l}3.74 \mathrm{e}-05 * * * \\
(7.37 \mathrm{e}-06)\end{array}$ \\
\hline Inc Dist to UC $>50,000$ & & $\begin{array}{l}-0.164 * * * \\
(0.0387)\end{array}$ & & $\begin{array}{l}-0.00924 \\
(0.0617)\end{array}$ & & $\begin{array}{l}0.302 \\
(0.262)\end{array}$ \\
\hline Square of Inc Dist to UC $>50,000$ & & $0.00233 * *$ & & $0.0222 *$ & & -0.0240 \\
\hline
\end{tabular}


Table 5 (continued)

\begin{tabular}{|c|c|c|c|c|c|c|}
\hline \multirow[t]{2}{*}{ Dependent variable: start-up rate } & \multicolumn{2}{|l|}{ NL } & \multicolumn{2}{|l|}{$\mathrm{BE}$} & \multicolumn{2}{|l|}{ SE } \\
\hline & Model 1 & Model 2 & Model 1 & Model 2 & Model 1 & Model 2 \\
\hline & & $(0.00110)$ & & $(0.0129)$ & & $(0.0305)$ \\
\hline \multirow[t]{2}{*}{ Inc Dist to UC > 100,000 } & & $-0.0627 * * *$ & & -0.00729 & & 0.0316 \\
\hline & & $(0.0168)$ & & $(0.0118)$ & & $(0.0643)$ \\
\hline \multirow[t]{2}{*}{ Square of Inc Dist to UC $>100,000$} & & 0.000772 & & -0.000714 & & -0.000154 \\
\hline & & $(0.000590)$ & & $(0.000552)$ & & $(0.00336)$ \\
\hline \multirow[t]{2}{*}{ Inc Dist to $\mathrm{UC}>250,000$} & & $-0.0421 * * *$ & & $-0.00538^{*}$ & & $-0.0108 * * *$ \\
\hline & & $(0.00631)$ & & $(0.00316)$ & & $(0.00134)$ \\
\hline \multirow[t]{2}{*}{ Square of Inc Dist to UC $>250,000$} & & $8.10 \mathrm{e}-05$ & & $-5.70 \mathrm{e}-05$ & & $1.54 \mathrm{e}-05 * * *$ \\
\hline & & $(6.11 \mathrm{e}-05)$ & & $(5.97 e-05)$ & & $(3.56 \mathrm{e}-06)$ \\
\hline \multirow[t]{2}{*}{ Age $<15$} & $0.348 * *$ & $0.257 * *$ & $-0.297 * * *$ & -0.119 & 0.0925 & 0.153 \\
\hline & $(0.140)$ & $(0.130)$ & $(0.0949)$ & $(0.0897)$ & $(0.166)$ & $(0.140)$ \\
\hline \multirow[t]{2}{*}{ Age $15-25$} & -0.0942 & -0.0799 & $0.252 * * *$ & $0.373 * * *$ & -0.120 & -0.0147 \\
\hline & $(0.114)$ & $(0.106)$ & $(0.0784)$ & $(0.0779)$ & $(0.137)$ & $(0.119)$ \\
\hline \multirow[t]{2}{*}{ Age $25-35$} & -0.0440 & 0.00327 & $0.277 * * *$ & $0.404 * * *$ & -0.0450 & $0.173 *$ \\
\hline & $(0.137)$ & $(0.132)$ & $(0.0850)$ & $(0.0794)$ & $(0.119)$ & $(0.102)$ \\
\hline Age $35-50$ & Reference & Reference & Reference & Reference & Reference & Reference \\
\hline \multirow[t]{2}{*}{ Age $50-65$} & -0.201 & -0.129 & $-0.153^{*}$ & -0.0840 & $0.439 * * *$ & $0.446 * * *$ \\
\hline & $(0.151)$ & $(0.139)$ & $(0.0901)$ & $(0.0848)$ & $(0.130)$ & $(0.108)$ \\
\hline \multirow[t]{2}{*}{ Age $65+$} & $0.152 *$ & $0.281 * * *$ & $0.121^{* *}$ & $0.272 * * *$ & 0.0439 & $0.182 * *$ \\
\hline & $(0.0916)$ & $(0.0865)$ & $(0.0580)$ & $(0.0567)$ & $(0.102)$ & $(0.0866)$ \\
\hline \multirow[t]{2}{*}{ Higher educated } & $0.200 * * *$ & $0.150 * * *$ & $0.131 * * *$ & $0.129 * * *$ & $0.0861 * * *$ & $0.115^{* * *}$ \\
\hline & $(0.0219)$ & $(0.0218)$ & $(0.0103)$ & $(0.0106)$ & $(0.0215)$ & $(0.0189)$ \\
\hline \multirow[t]{2}{*}{ Immigrant } & $0.0968 * * *$ & $0.101 * * *$ & -0.000650 & 0.000925 & -0.00335 & $-0.0300 * *$ \\
\hline & $(0.0219)$ & $(0.0207)$ & $(0.00385)$ & $(0.00359)$ & $(0.0141)$ & $(0.0127)$ \\
\hline \multirow[t]{2}{*}{ Unemployment } & 0.0978 & 0.129 & 0.0158 & 0.0220 & $-0.174 * * *$ & -0.0235 \\
\hline & $(0.126)$ & $(0.116)$ & $(0.0172)$ & $(0.0188)$ & $(0.0660)$ & $(0.0554)$ \\
\hline \multirow[t]{2}{*}{ Service } & $0.0884 * * *$ & $0.0757 * * *$ & 0.00952 & 0.00284 & $0.203 * * *$ & $0.155 * * *$ \\
\hline & $(0.0173)$ & $(0.0160)$ & $(0.00785)$ & $(0.00738)$ & $(0.0177)$ & $(0.0158)$ \\
\hline \multirow[t]{2}{*}{ Public } & 0.0128 & 0.0103 & $-0.0473^{* * *}$ & $-0.0413^{* * *}$ & -0.0407 & -0.0170 \\
\hline & $(0.0154)$ & $(0.0145)$ & $(0.00687)$ & $(0.00639)$ & $(0.0257)$ & $(0.0213)$ \\
\hline \multirow[t]{2}{*}{ Constant } & -1.227 & 0.265 & 5.835 & -4.499 & -6.255 & $-15.10 * *$ \\
\hline & $(8.831)$ & $(8.181)$ & $(5.411)$ & $(5.101)$ & $(9.063)$ & (7.599) \\
\hline Log likelihood & -849.4091 & -809.8983 & -1022.125 & -969.3787 & -485.6899 & -423.0079 \\
\hline AIC & 1724.818 & 1663.797 & 2070.25 & 1982.757 & 997.3799 & 890.0158 \\
\hline Wald $\mathrm{Chi}^{2}$ & $390.33 * * *$ & $561.68 * * *$ & $376.65^{* * * *}$ & $566.06 * * *$ & $558.51 * * *$ & $1017.37 * * * *$ \\
\hline Observations & 405 & 405 & 589 & 589 & 290 & 290 \\
\hline
\end{tabular}

Standard errors in parentheses

$* * * p<0.01 ; * * p<0.05 ; * p<0.1$ 


\section{Appendix II}

Table 6 Regression results: maximum likelihood estimation excluding incremental distances to UC $>50,000$ and $>100,000$

\begin{tabular}{|c|c|c|c|c|c|c|}
\hline \multirow[t]{2}{*}{ Dependent variable: start-up rate } & \multicolumn{2}{|l|}{ NL } & \multicolumn{2}{|l|}{$\mathrm{BE}$} & \multicolumn{2}{|l|}{ SE } \\
\hline & Model 1 & Model 2 & Model 1 & Model 2 & Model 1 & Model 2 \\
\hline Population density (ln) & $\begin{array}{l}-0.386^{* * *} \\
(0.146)\end{array}$ & $\begin{array}{l}-0.410^{* *} \\
(0.164)\end{array}$ & $\begin{array}{l}-0.211 * * * \\
(0.0679)\end{array}$ & $\begin{array}{l}-0.475^{* * * *} \\
(0.104)\end{array}$ & $\begin{array}{l}-0.0499 \\
(0.0880)\end{array}$ & $\begin{array}{l}-0.587 * * * \\
(0.109)\end{array}$ \\
\hline Spatial lag population density & & $\begin{array}{l}-0.00216^{* * *} \\
(0.000489)\end{array}$ & & $\begin{array}{l}0.000209 * \\
(0.000115)\end{array}$ & & $\begin{array}{l}0.00181 * * * \\
(0.000287)\end{array}$ \\
\hline Dist to nearest UC & & $\begin{array}{l}-0.0330^{*} \\
(0.0199)\end{array}$ & & $\begin{array}{l}0.00262 \\
(0.00744)\end{array}$ & & $\begin{array}{l}-0.00789 \text { *** } \\
(0.00163)\end{array}$ \\
\hline Square of dist to nearest UC & & $\begin{array}{l}0.000785 \\
(0.000911)\end{array}$ & & $\begin{array}{l}-0.000410^{* * *} \\
(0.000106)\end{array}$ & & $\begin{array}{l}3.87 \mathrm{e}-05^{* * *} \\
(7.31 \mathrm{e}-06)\end{array}$ \\
\hline Inc Dist to UC $>250,000$ & & $\begin{array}{l}-0.0384^{* * *} \\
(0.00589)\end{array}$ & & $\begin{array}{l}-0.00681^{* *} \\
(0.00292)\end{array}$ & & $\begin{array}{l}-0.0108 * * * \\
(0.00132)\end{array}$ \\
\hline Square of Inc Dist to UC $>250,000$ & & $\begin{array}{l}0.000182 * * \\
(7.58 \mathrm{e}-05)\end{array}$ & & $\begin{array}{l}-2.06 \mathrm{e}-05 \\
(5.69 \mathrm{e}-05)\end{array}$ & & $\begin{array}{l}1.52 \mathrm{e}-05^{* * *} \\
(3.54 \mathrm{e}-06)\end{array}$ \\
\hline Age $<15$ & $\begin{array}{l}0.348^{* *} \\
(0.140)\end{array}$ & $\begin{array}{l}0.233^{*} \\
(0.131)\end{array}$ & $\begin{array}{l}-0.297 * * * \\
(0.0949)\end{array}$ & $\begin{array}{l}-0.196^{* *} \\
(0.0907)\end{array}$ & $\begin{array}{l}0.0925 \\
(0.166)\end{array}$ & $\begin{array}{l}0.191 \\
(0.140)\end{array}$ \\
\hline Age $15-25$ & $\begin{array}{l}-0.0942 \\
(0.114)\end{array}$ & $\begin{array}{l}-0.0880 \\
(0.108)\end{array}$ & $\begin{array}{l}0.252 * * * \\
(0.0784)\end{array}$ & $\begin{array}{l}0.381 * * * \\
(0.0804)\end{array}$ & $\begin{array}{l}-0.120 \\
(0.137)\end{array}$ & $\begin{array}{l}0.0545 \\
(0.118)\end{array}$ \\
\hline Age $25-35$ & $\begin{array}{l}-0.0440 \\
(0.137)\end{array}$ & $\begin{array}{l}-0.0337 \\
(0.132)\end{array}$ & $\begin{array}{l}0.277 * * * \\
(0.0850)\end{array}$ & $\begin{array}{l}0.371 * * * \\
(0.0810)\end{array}$ & $\begin{array}{l}-0.0450 \\
(0.119)\end{array}$ & $\begin{array}{l}0.171 * \\
(0.0995)\end{array}$ \\
\hline Age $35-50$ & Reference & Reference & Reference & Reference & Reference & Reference \\
\hline Age $50-65$ & $\begin{array}{l}-0.201 \\
(0.151)\end{array}$ & $\begin{array}{l}-0.170 \\
(0.140)\end{array}$ & $\begin{array}{l}-0.153 * \\
(0.0901)\end{array}$ & $\begin{array}{l}-0.124 \\
(0.0872)\end{array}$ & $\begin{array}{l}0.439 * * * \\
(0.130)\end{array}$ & $\begin{array}{l}0.473 * * * \\
(0.107)\end{array}$ \\
\hline Age $65+$ & $\begin{array}{l}0.152 * \\
(0.0916)\end{array}$ & $\begin{array}{l}0.203 * * \\
(0.0858)\end{array}$ & $\begin{array}{l}0.121 * * \\
(0.0580)\end{array}$ & $\begin{array}{l}0.212 * * * \\
(0.0562)\end{array}$ & $\begin{array}{l}0.0439 \\
(0.102)\end{array}$ & $\begin{array}{l}0.213 * * \\
(0.0860)\end{array}$ \\
\hline Higher educated & $\begin{array}{l}0.200 * * * \\
(0.0219)\end{array}$ & $\begin{array}{l}0.175^{* * *} \\
(0.0211)\end{array}$ & $\begin{array}{l}0.131 * * * \\
(0.0103)\end{array}$ & $\begin{array}{l}0.129 * * * \\
(0.0109)\end{array}$ & $\begin{array}{l}0.0861 * * * \\
(0.0215)\end{array}$ & $\begin{array}{l}0.109^{* * * *} \\
(0.0184)\end{array}$ \\
\hline Immigrant & $\begin{array}{l}0.0968^{* * * *} \\
(0.0219)\end{array}$ & $\begin{array}{l}0.0883^{* * * *} \\
(0.0210)\end{array}$ & $\begin{array}{l}-0.000650 \\
(0.00385)\end{array}$ & $\begin{array}{l}-0.000238 \\
(0.00367)\end{array}$ & $\begin{array}{l}-0.00335 \\
(0.0141)\end{array}$ & $\begin{array}{l}-0.0271^{* *} \\
(0.0123)\end{array}$ \\
\hline Unemployment & $\begin{array}{l}0.0978 \\
(0.126)\end{array}$ & $\begin{array}{l}0.104 \\
(0.118)\end{array}$ & $\begin{array}{l}0.0158 \\
(0.0172)\end{array}$ & $\begin{array}{l}0.0281 \\
(0.0186)\end{array}$ & $\begin{array}{l}-0.174 * * * \\
(0.0660)\end{array}$ & $\begin{array}{l}-0.0374 \\
(0.0547)\end{array}$ \\
\hline Service & $\begin{array}{l}0.0884 * * * \\
(0.0173)\end{array}$ & $\begin{array}{l}0.0699 * * * \\
(0.0163)\end{array}$ & $\begin{array}{l}0.00952 \\
(0.00785)\end{array}$ & $\begin{array}{l}0.00524 \\
(0.00768)\end{array}$ & $\begin{array}{l}0.203^{* * * *} \\
(0.0177)\end{array}$ & $\begin{array}{l}0.159 * * * \\
(0.0156)\end{array}$ \\
\hline Public & $\begin{array}{l}0.0128 \\
(0.0154)\end{array}$ & $\begin{array}{l}0.0129 \\
(0.0146)\end{array}$ & $\begin{array}{l}-0.0473 * * * \\
(0.00687)\end{array}$ & $\begin{array}{l}-0.0427^{* * * *} \\
(0.00658)\end{array}$ & $\begin{array}{l}-0.0407 \\
(0.0257)\end{array}$ & $\begin{array}{l}-0.00896 \\
(0.0210)\end{array}$ \\
\hline Constant & $\begin{array}{l}-1.227 \\
(8.831)\end{array}$ & $\begin{array}{l}2.145 \\
(8.207)\end{array}$ & $\begin{array}{l}5.835 \\
(5.411)\end{array}$ & $\begin{array}{l}-0.717 \\
(5.190)\end{array}$ & $\begin{array}{l}-6.255 \\
(9.063)\end{array}$ & $\begin{array}{l}-18.12^{* *} \\
(7.590)\end{array}$ \\
\hline Log likelihood & -849.4091 & -818.3454 & -1022.125 & -987.2464 & -485.6899 & -423.8885 \\
\hline $\mathrm{AIC}$ & 1724.818 & 1672.691 & 2070.25 & 2010.493 & 997.3799 & 883.7769 \\
\hline Wald $\mathrm{Chi}^{2}$ & $390.33^{* * * *}$ & $522.19^{* * *}$ & $376.65^{* * *}$ & $498.06^{* * *}$ & $558.51^{* * *}$ & $1009.45^{* * *}$ \\
\hline Observations & 405 & 405 & 589 & 589 & 290 & 290 \\
\hline
\end{tabular}

Standard errors in parentheses

$* * * p<0.01 ; * * p<0.05 ; * p<0.1$ 


\section{Appendix III}

Table 7 Regression results: maximum likelihood estimation for Belgium excluding Wallonia

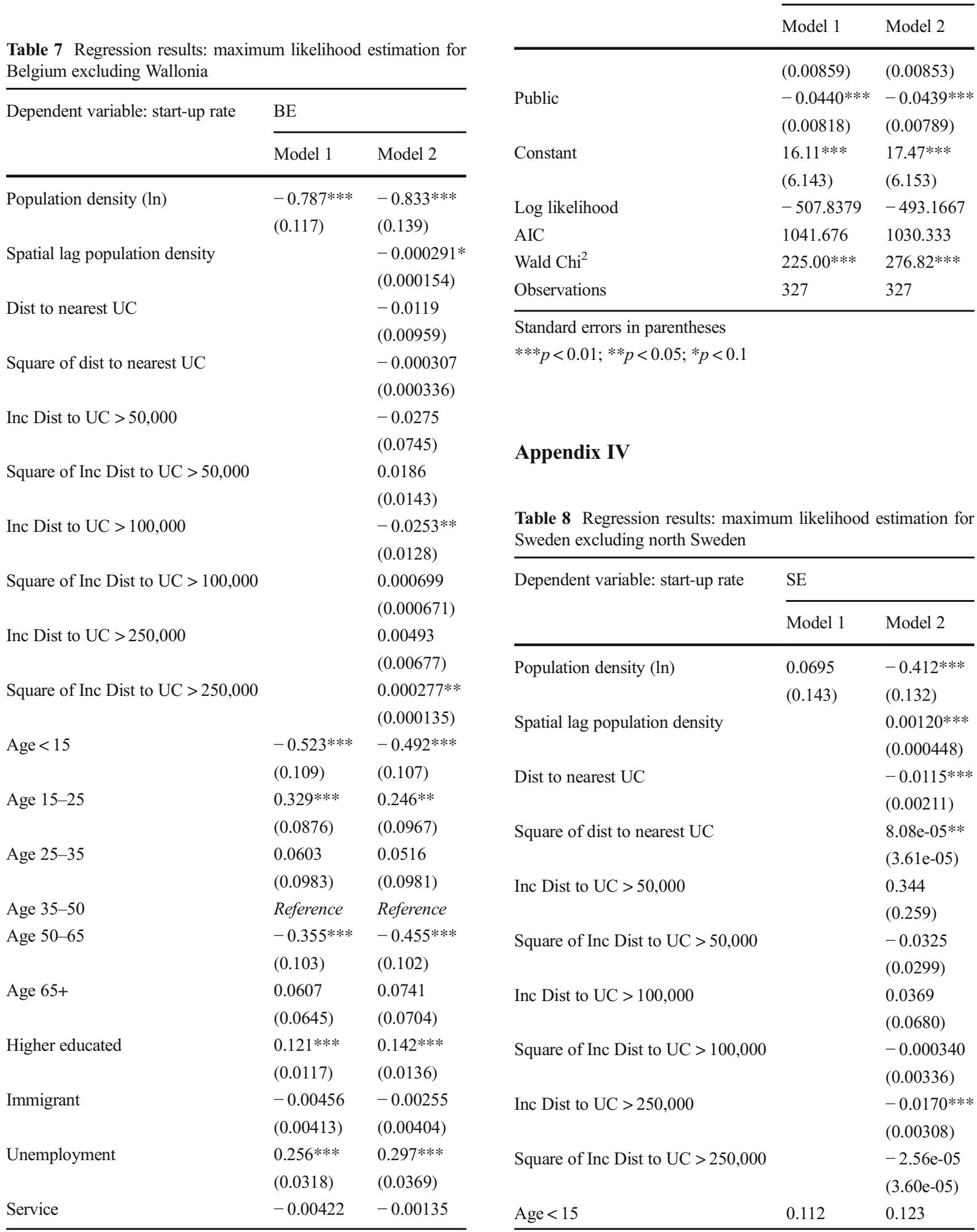

Table 7 (continued)

Dependent variable: start-up rate $\mathrm{BE}$

Standard errors in parentheses

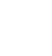


Table 8 (continued)

\begin{tabular}{|c|c|c|}
\hline \multirow[t]{2}{*}{ Dependent variable: start-up rate } & \multicolumn{2}{|l|}{$\mathrm{SE}$} \\
\hline & Model 1 & Model 2 \\
\hline & $(0.197)$ & $(0.167)$ \\
\hline \multirow[t]{2}{*}{ Age $15-25$} & -0.124 & 0.0163 \\
\hline & $(0.149)$ & $(0.133)$ \\
\hline \multirow[t]{2}{*}{ Age $25-35$} & -0.0403 & 0.178 \\
\hline & $(0.133)$ & $(0.116)$ \\
\hline Age $35-50$ & Reference & Reference \\
\hline \multirow[t]{2}{*}{ Age $50-65$} & $0.498 * * *$ & $0.385 * * *$ \\
\hline & $(0.147)$ & $(0.125)$ \\
\hline \multirow[t]{2}{*}{ Age $65+$} & 0.0371 & $0.228 * *$ \\
\hline & $(0.123)$ & $(0.106)$ \\
\hline \multirow[t]{2}{*}{ Higher educated } & $0.0867 * * *$ & $0.0998 * * *$ \\
\hline & $(0.0233)$ & $(0.0200)$ \\
\hline \multirow[t]{2}{*}{ Immigrant } & 0.000208 & $-0.0477 * * *$ \\
\hline & $(0.0170)$ & $(0.0157)$ \\
\hline \multirow[t]{2}{*}{ Unemployment } & $-0.161 * *$ & -0.0463 \\
\hline & $(0.0733)$ & (0.0619) \\
\hline \multirow[t]{2}{*}{ Service } & $0.191 * * *$ & $0.135 * * *$ \\
\hline & $(0.0198)$ & $(0.0180)$ \\
\hline \multirow[t]{2}{*}{ Public } & -0.0157 & -0.0251 \\
\hline & $(0.0299)$ & $(0.0252)$ \\
\hline \multirow[t]{2}{*}{ Constant } & -8.247 & -13.47 \\
\hline & $(10.54)$ & $(9.033)$ \\
\hline Log likelihood & -378.3832 & -329.8316 \\
\hline AIC & 782.7665 & 703.6631 \\
\hline Wald $\mathrm{Chi}^{2}$ & $561.40 * * *$ & $975.44 * * *$ \\
\hline Observations & 231 & 231 \\
\hline
\end{tabular}

Standard errors in parentheses

$* * * p<0.01 ; * * p<0.05 ; * p<0.1$

Open Access This article is distributed under the terms of the Creative Commons Attribution 4.0 International License (http:// creativecommons.org/licenses/by/4.0/), which permits unrestricted use, distribution, and reproduction in any medium, provided you give appropriate credit to the original author(s) and the source, provide a link to the Creative Commons license, and indicate if changes were made.

\section{References}

Acs, Z. J., \& Szerb, L. (2007). Entrepreneurship, economic growth and public policy. Small Business Economics, 28(2-3), 109122. https://doi.org/10.1007/s11187-006-9012-3.
Aidis, R., Estrin, S., \& Mickiewicz, T. M. (2012). Size matters: Entrepreneurial entry and government. Small Business Economics, 39(1), 119-139. https://doi.org/10.1007/s11187010-9299-y.

Alonso, W. (1973). Urban zero population growth. Daedalus, 109 , 191-206.

Andersson, M., \& Karlsson, C. (2004). The role of accessibility for the performance of regional innovation systems. In $\mathrm{C}$. Karlsson, P. Flensburg, \& A. Hortes (Eds.), Knowledge spillovers and knowledge management (pp. 283-310). Cheltenham: Edward Elgar.

Andersson, M., \& Koster, S. (2011). Sources of persistence in regional start-up rates-evidence from Sweden. Journal of Economic Geography, 11(1), 179-201. https://doi. org/10.1093/jeg/lbp069.

Andersson, M., \& Karlsson, C. (2007). Knowledge in regional economic growth-The role of knowledge accessibility. Industry and Innovation, 14(2), 129-149. https://doi. org/10.1080/13662710701252450.

Andersson, M., Koster, S., \& Lavesson, N. (2016). Are start-ups the same everywhere? The urban-rural skill gap in Swedish entrepreneurship. In E. A. Mack \& H. Qian (Eds.), Geographies of entrepreneurship (pp. 122-142). Abingdon: Routledge.

Anselin, L., \& Bera, A. K. (1998). Spatial dependence in linear regression models with an introduction to spatial econometrics. In A. Ullah \& D. E. A. Giles (Eds.), Handbook of applied economic statistics (pp. 237-289). New York: Marcel Dekker.

Anselin, L., Varga, A., \& Acs, Z. J. (2000). Geographic and sectoral characteristics of academic knowledge externalities. Papers in Regional Science, 79(4), 435-443. https://doi. org/10.1111/j.1435-5597.2000.tb01766.x.

Apparicio, P., Abdelmajid, M., Riva, M., \& Shearmur, R. (2008). Comparing alternative approaches to measuring the geographical accessibility of urban health services: Distance types and aggregation-error issues. International Journal of Health Geographics, 7(1), 1-13. https://doi.org/10.1186 /1476-072X-7-7.

Armington, C., \& Acs, Z. J. (2002). The determinants of regional variation in new firm formation. Regional Studies, 36(1), 3345. https://doi.org/10.1080/00343400120099843.

Audretsch, D. B., \& Fritsch, M. (1994). On the measurement of entry rates. Empirica, 21(1), 105-113. https://doi. org/10.1007/BF01383974.

Audretsch, D. B., Belitski, M., \& Desai, S. (2015). Entrepreneurship and economic development in cities. The Annals of Regional Science, 55(1), 33-60. https://doi. org/10.1007/s00168-015-0685-x.

Balcerzak, A. P., \& Pietrzak, M. B. (2017). Human development and quality of institutions in highly developed countries. In M. Bilgin, H. Danis, E. Demir, \& U. Can (Eds.), Financial environment and business development, Eurasian studies in business and economics 4 (pp. 231-241). Cham: Springer.

Baptista, R., \& Mendonça, J. (2010). Proximity to knowledge sources and the location of knowledge-based start-ups. The Annals of Regional Science, 45(1), 5-29. https://doi. org/10.1007/s00168-009-0289-4.

Baptista, R., Escária, V., \& Madruga, P. (2008). Entrepreneurship, regional development and job creation: The case of Portugal. 
Small Business Economics, 30(1), 49-58. https://doi. org/10.1007/s11187-007-9055-0.

Bosma, N., \& Sternberg, R. (2014). Entrepreneurship as an urban event? Empirical evidence from European cities. Regional Studies, 48(6), 1016-1033. https://doi.org/10.1080 /00343404.2014.904041.

Bosma, N., Van Stel, A., \& Suddle, K. (2008). The geography of new firm formation: Evidence from independent start-ups and new subsidiaries in the Netherlands. International Entrepreneurship and Management Journal, 4, 129-146. https://doi.org/10.1007/s11365-007-0058-8.

Burger, M. J., Meijers, E. J., Hoogerbrugge, M. M., \& Masip Tresserra, J. (2015). Borrowed size, agglomeration shadows and cultural amenities in North-West Europe. European Planning Studies, 23(6), 1090-1109. https://doi.org/10.1080 /09654313.2014.905002.

Camagni, R., Capello, R., \& Caragliu, A. (2015). The rise of second-rank cities: What role for agglomeration economies? European Planning Studies, 23(6), 1069-1089. https://doi. org/10.1080/09654313.2014.904999.

Colombo, M. G., \& Delmastro, M. (2001). Technology-based entrepreneurs: Does internet make a difference? Small Business Economics, 16(3), 177-190. https://doi. org/10.1023/A:1011127205758.

Cowling, M. (2000). Are entrepreneurs different across countries? Applied Economics Letters, 7(12), 785-789. https://doi. org/10.1080/135048500444804.

Dahl, M. S., \& Sorenson, O. (2012). Home sweet home: Entrepreneurs' location choices and the performance of their ventures. Management Science, 58(6), 1059-1071. https://doi.org/10.1287/mnsc.1110.1476.

Delfmann, H., \& Koster, S. (2013). Why start a business in a declining rural area with an ageing society? A UK-NL case study. Paper presented at the 42nd annual RSAI-BIS conference, 20-22 August, 2013, Cambridge, United Kingdom.

Delfmann, H., Koster, S., McCann, P., \& Van Dijk, J. (2014). Population change and new firm formation in urban and rural regions. Regional Studies, 48(6), 1034-1050. https://doi. org/10.1080/00343404.2013.867430.

Dijkstra, L. \& Poelman, H. (2012). Cities in Europe: The new OECD-EC definition. Regional Focus 01/2012. Brussels: European Commission.

Duranton, G. (2014). Agglomeration and jobs. In M. M. Fischer \& P. Nijkamp (Eds.), Handbook of Regional Science (pp. 631648). Berlin Heidelberg: Springer-Verlag. https://doi. org/10.1007/978-3-642-23430-9_33.

Eliasson, K., \& Westlund, H. (2013). Attributes influencing selfemployment propensity in urban and rural Sweden. The Annals of Regional Science, 50(2), 479-514. https://doi. org/10.1007/s00168-012-0501-9.

Figueiredo, O., Guimaraes, P., \& Woodward, D. (2002). Homefield advantage: Location decisions of Portuguese entrepreneurs. Journal of Urban Economics, 52(2), 341-361. https://doi.org/10.1016/S0094-1190(02)00006-2.

Freire-Gibb, L. C., \& Nielsen, K. (2014). Entrepreneurship within urban and rural areas: Creative people and social networks. Regional Studies, 48(1), 139-153. https://doi.org/10.1080 /00343404.2013.808322.

Frenken, K., \& Boschma, R. A. (2007). A theoretical framework for evolutionary economic geography: Industrial dynamics and urban growth as a branching process. Journal of
Economic Geography, 7(5), 635-649. https://doi. org/10.1093/jeg/lbm018.

Fritsch, M., \& Falck, O. (2007). New business formation by industry over space and time: A multidimensional analysis. Regional Studies, 41(2), 157-172. https://doi.org/10.1080 /00343400600928301.

Fritsch, M., \& Mueller, P. (2007). The persistence of regional new business formation-activity over time-assessing the potential of policy promotion programs. Journal of Evolutionary Economics, 17, 299-315. https://doi.org/10.1007/s00191-007-0056-6.

Gibbons, S., \& Overman, H. G. (2012). Mostly pointless spatial econometrics? Journal of Regional Science, 52(2), 172-191. https://doi.org/10.1111/j.1467-9787.2012.00760.x.

Glaeser, E. L., Kerr, W. R., \& Ponzetto, G. A. M. (2010). Clusters of entrepreneurship. Journal of Urban Economics, 67(1), 150-168. https://doi.org/10.1016/j.jue.2009.09.008.

Kelley, D., Singer, S. \& Herrington, M. (2016). Global Entrepreneurship Monitor. 2015/16 Global Report. London: Global Entrepreneurship Research.

Kirchhoff, B., Newbert, S., Hasan, I., \& Armington, C. (2007). The influence of university R\&D expenditures on new business formations and employment growth. Entrepreneurship: Theory \& Practice, 31(4), 543-559. https://doi.org/10.1111 j.1540-6520.2007.00187.x.

Koopmans, R. (2010). Trade-offs between equality and difference: Immigrant integration, multiculturalism and the welfare state in cross-national perspective. Journal of Ethnic and Migration Studies, 36(1), 1-26. https://doi.org/10.1080 /13691830903250881.

Koster, S. (2007). Window on the Netherlands: The entrepreneurial and replication function of new firm formation. Tijdschrift voor Economische en Sociale Geografie, 98(5), 667-674. https://doi.org/10.1111/j.1467-9663.2007.00432.x.

Lavesson, N. (2017). How does distance to urban centres influence necessity and opportunity-based firm start-ups? Papers in Regional Science. https://doi.org/10.1111/pirs.12289.

Mason, C. M., Carter, S., \& Tagg, S. (2011). Invisible businesses: The characteristics of home-based businesses in the United Kingdom. Regional Studies, 45(5), 625-639. https://doi. org/10.1080/00343401003614241.

Meijers, E. J., \& Burger, M. J. (2015). Stretching the concept of 'borrowed size'. Urban Studies, 54(1), 269-291. https://doi. org/10.1177/0042098015597642.

Meijers, E. J., Burger, M. J., \& Hoogerbrugge, M. M. (2016). Borrowing size in networks of cities: City size, network connectivity and metropolitan functions in Europe. Papers in Regional Science, 95(1), 181-198. https://doi.org/10.1111 /pirs. 12181.

Michelacci, C., \& Silva, O. (2007). Why so many local entrepreneurs? The Review of Economics and Statistics, 89(4), 615633. https://doi.org/10.1162/rest.89.4.615.

Nyström, K. (2008). The institutions of economic freedom and entrepreneurship: Evidence from panel data. Public Choice, 136, 269-282. https://doi.org/10.1007/s11127-008-9295-9.

Organization for Economic Co-operation and Development (OECD). (2008). OECD rural policy reviews: Netherlands. Paris: OECD.

Partridge, M. D., Bollman, R. D., Olfert, M. R., \& Alasi, A. (2007). Riding the wave of urban growth in the countryside: Spread, backwash or stagnation? Land Economics, 83(2), 128-152. https://doi.org/10.3368/le.83.2.128. 
Partridge, M. D., Rickman, D. S., Ali, K., \& Olfert, M. R. (2008). The geographic diversity of U.S. nonmetropolitan growth dynamics: A geographically weighted regression approach. Land Economics, 84(2), 241-266. https://doi.org/10.3368 /le.84.2.241.

Partridge, M. D., Rickman, D. S., Ali, K., \& Olfert, M. R. (2009). Do new economic geography agglomeration shadows underlie current population dynamics across the urban hierarchy? Papers in Regional Science, 88(2), 445-466. https://doi. org/10.1111/j.1435-5957.2008.00211.x.

Pettersson, L., Sjölander, P., \& Widell, L. M. (2010). Firm formation in rural and urban regions explained by demographical structure. Paper presented at the 50th European Regional Science Association (ERSA) Conference, Jönköping, 19-23 August 2010.

Polèse, M., \& Shearmur, R. (2004). Is distance really dead? Comparing industrial patterns over time in Canada. International Regional Science Review, 27(4), 431-457. https://doi.org/10.1177/0160017604267637.

Pumain, D. (2006). Alternative explanations of hierarchical differentiation in urban systems. In D. Pumain (Ed.), Hierarchy in Natural and Social Sciences (pp. 169-222). Dordrecht: Springer.

Quinn, J. F. (1980). Labour-force participation patterns of older self-employed workers. Social Security Bulletin, 43, 17-28.

Sandow, E. (2008). Commuting behaviour in sparsely populated areas: Evidence from northern Sweden. Journal of Transport Geography, 16(1), 14-27. https://doi.org/10.1016/j. jtrangeo.2007.04.004.

Shearmur, R. (2011). Innovation, regions and proximity: From neo-regionalism to spatial analysis. Regional Studies, 45(9), 1225-1243. https://doi.org/10.1080/00343404.2010.484416.

Stam, E. (2009). Entrepreneurship, evolution and geography. Papers in Evolutionary Economic Geography, 9(13), 1-23.

Statistics Netherlands. (2016). Banen werknemers en afstand woon-werk; woon- en werkregio's. Retrieved through Statline (http://statline.cbs.nl).
Sternberg, R. (2011). Regional determinants of entrepreneurial activities - theories and empirical evidence. In M. Fritsch (Ed.), Handbook of research and entrepreneurship and regional development (pp. 33-57). Cheltenham: Edward Elgar Publishing.

Van Oort, F. G., \& Atzema, O. (2004). On the conceptualization of agglomeration economies: The case of new firm formation in the Dutch ICT sector. The Annals of Regional Science, 38, 263-290. https://doi.org/10.1007/s00168-004-0195-8.

van Oort, F.G. \& Stam, E. (2009). Agglomeration economies and firm growth: testing for spatial externalities in the Dutch ICT industry. In B. Johansson, C. Karlsson \& R. Stough (Eds.), Innovation, Agglomeration, and Regional Competition (pp. 346-374). Cheltenham: Edward Elgar Publishing.

Van Stel, A., \& Suddle, K. (2008). The impact of new firm formation on regional development in the Netherlands. Small Business Economics, 30(1), 30-47. https://doi. org/10.1007/s11187-007-9054-1.

Verhetsel, A., Van Hecke, E., Thomas, I., Beelen, M., Halleux, J. M., Lambotte, J. M., Rixhon, G., \& Mérenne-Schoumaker, B. (2009). Pendel in België. De woon-werkverplaatsingen. De woon-schoolverplaatsingen. Brussel: Statistics Belgium, FOD Economie.

Verheul, I., Wennekers, S., Audretsch, D., \& Thurik, R. (2002). An eclectic theory of entrepreneurship: Policies, institutions and culture. In D. Audretsch, R. Thurik, I. Verheul, \& S. Wennekers (Eds.), Entrepreneurship: Determinants and policy in a European-US comparison (pp. 11-81). New York: Springer.

Wagner, J., \& Sternberg, R. (2004). Start-up activities, individual characteristics, and the regional milieu: Lessons for entrepreneurship support policies from German micro data. The Annals of Regional Science, 38, 219-240. https://doi. org/10.1007/s00168-004-0193-x.

Westlund, H., Larsson, J. P., \& Olsson, A. R. (2014). Start-ups and local entrepreneurial social capital in the municipalities of Sweden. Regional Studies, 48(6), 974-994. https://doi. org/10.1080/00343404.2013.865836. 